\title{
Development of a Nitrous Oxide Routine for the SWAT Model to Assess Greenhouse Gas Emissions from Agroecosystems
}

10 Abstract

11 Greenhouse gas (GHG) emissions from agroecosystems, particularly nitrous oxide $\left(\mathrm{N}_{2} \mathrm{O}\right)$, are an 12 increasing concern. To quantify $\mathrm{N}_{2} \mathrm{O}$ emissions from agroecosystems, which occur as a result of nitrogen 13 (N) cycling, a new physically based routine was developed for the Soil and Water Assessment Tool 14 (SWAT) model to predict $\mathrm{N}_{2} \mathrm{O}$ flux during denitrification and an existing nitrification routine was

15 modified to capture $\mathrm{N}_{2} \mathrm{O}$ flux during this process. The new routines predict $\mathrm{N}_{2} \mathrm{O}$ emissions by coupling 16 the carbon (C) and $\mathrm{N}$ cycles with soil moisture/temperature and $\mathrm{pH}$ in SWAT. The model uses reduction 17 functions to predict total denitrification $\left(\mathrm{N}_{2}+\mathrm{N}_{2} \mathrm{O}\right)$ and partitions $\mathrm{N}_{2}$ from $\mathrm{N}_{2} \mathrm{O}$ using a ratio method. The 18 modified SWAT nitrification routine likewise predicts $\mathrm{N}_{2} \mathrm{O}$ emissions using reduction functions. The new

19 denitrification routine and modified nitrification routine were tested using GRACEnet data at University

20 Park, Pennsylvania, and West Lafayette, Indiana. Results showed strong correlations between plot

21 measurements of $\mathrm{N}_{2} \mathrm{O}$ flux and the model predictions for both test sites and suggest that $\mathrm{N}_{2} \mathrm{O}$ emissions

22 are particularly sensitive to soil $\mathrm{pH}$ and soil $\mathrm{N}$, and moderately sensitive to soil temperature/moisture 23 and total soil C levels.

25 Key words: Greenhouse Gas Emissions, SWAT, Nitrous Oxide, pH, Denitrification, Nitrification, Soil

26 Carbon, Spatial Distribution

\section{Software Availability}

29 Model name: SWAT-GHG model. Developed by M.B. Wagena (bwmoges4@vt.edu) and Z.M. Easton

30 (zeaston@vt.edu), Department of Biological Systems Engineering, Virginia Tech, Blacksburg, VA 24060.

31 Year available: 2016. Availability: Contact developers. Cost: Free and open source. Language: Fortran. 


\section{Introduction}

33 Greenhouse gas (GHG) emissions from agroecosystems, particularly nitrous oxide $\left(\mathrm{N}_{2} \mathrm{O}\right)$, are of 34 increasing importance and a major contributor to global climate change. $\mathrm{N}_{2} \mathrm{O}$ is a potent GHG, with 310 35 times the radiative forcing as $\mathrm{CO}_{2}$ (Beheydt et al., 2008; Jahangir et al., 2013) and is an intermediate product produced during both denitrification (Jahangir et al., 2013) and nitrification (Parton et al., 2001). Denitrification is the microbial process that converts reactive nitrate $\left(\mathrm{NO}_{3}{ }^{-}\right)$to $\mathrm{N}_{2} \mathrm{O}$ and unreactive dinitrogen $\left(\mathrm{N}_{2}\right)$, and is favored by anaerobic soil conditions, adequate soil $\mathrm{NO}_{3}{ }^{-}$and carbon (C) content, moderate to high soil temperature, neutral to basic soil $\mathrm{pH}$, and the presence of denitrifying microorganisms (Knowles, 1982; Parton et al., 1996). Nitrification is a microbial process that transforms ammonium $\left(\mathrm{NH}_{4}{ }^{+}\right)$to $\mathrm{NO}_{3}{ }^{-}$and occurs under aerobic soil conditions in the presence of adequate $\mathrm{NH}_{4}{ }^{+}$, high soil temperture, and high $\mathrm{pH}$. These factors vary in space and time in agroecosystems and interact with each other in complicated ways (Henault et al., 2000). Consequently, $\mathrm{N}_{2} \mathrm{O}$ emissions vary spatially across a landscape and temporarily over the course of a year (Groffman et al., 2009). Identifying when, where, and how these factors interact to form hotspots/hot moments of $\mathrm{N}_{2} \mathrm{O}$ emissions (e.g., areas or times of large emissions) is a current area of reseach and a dauting challenge. Thus, there is a need to develop integrated models capable of incorporating these relevant controls to predict $\mathrm{N}_{2} \mathrm{O}$ emission across a range of scales to better inform the selection of landscape management practices to reduce $\mathrm{N}_{2} \mathrm{O}$ emissions (Bruland et al., 2006; Clement et al., 2002; Mosier et al., 2002).

Numerous system dynamics models (Kelly et al., 2013) have been developed to predict $\mathrm{N}_{2} \mathrm{O}$ emissions. Most, however, were developed for more natural systems in the absence of anthropogenic $\mathrm{N}$ application, where the $\mathrm{N}$ and $\mathrm{C}$ cycles are more closely coupled and $\mathrm{N}$ is often limiting. Consequently, the need for new models that capture $\mathrm{N}_{2} \mathrm{O}$ emissions in landscapes with an abundance of bioavailable $\mathrm{N}$ is driven by the inability of models developed for natural systems, without $\mathrm{N}$ enrichment, to capture $\mathrm{N}_{2} \mathrm{O}$ emissions when the $\mathrm{N}$ and $\mathrm{C}$ cycles are decoupled as a result of this enrichment. Existing models widely vary in their concept and structure, with some empirically-based and some process-based, and range in scale from plot to global. Generally, $\mathrm{N}_{2} \mathrm{O}$ emission models can be classified based on their application (Shaffer, 2002): (1) relatively simple index or screening type models, (e.g. Intergovernmental Panel on Climate Change (IPPC) Tier 2 model), (2) empirically-based models, and (3) process-based models.

Empirical models rely on easily measurable parameters (e.g., soil moisture/temperature, $\mathrm{pH}$, and soil nutrients) and then use regression equations to relate them to $\mathrm{N}_{2} \mathrm{O}$ emissions (Heinen, 2006; Parton et al., 1996). Empirical models include WNMM (Li et al., 2007), NLEAP (Shaffer et al., 1991), EPIC (Williams, 
63 1990), DLEM (Tian et al., 2015), EXPERT-N (Priesack et al., 2001), and NEMIS (Henault \& Germon, 2000).

64 While these models are capable of predicting $\mathrm{N}_{2} \mathrm{O}$ emissions under relatively controlled and known 65 conditions, these models can be challenging to apply outside of the range of conditions for which they 66 were developed and thus have limited utility to drive landscape management or predict the effects of 67 processes such as climate change.

68 Most of the recent advances in $\mathrm{N}_{2} \mathrm{O}$ emission models have been made in process-based modeling, which 69 can generally be classified in to three model types (Parton et al., 1996): (1) microbial growth models, (2) 70 soil structure models, and (3) physically-based models.

71 Microbial growth models simulate $\mathrm{N}_{2} \mathrm{O}$ emissions by representing the dynamics of the microbial 72 community (Heinen, 2006; Parton et al., 1996). Examples of such models include the DENLEFWAT model 73 (Leffelaar, 1988; Leffelaar et al., 1988), DNDC model (Frolking et al., 1992; Li et al., 1997), NLOSS model 74 (Riley et al., 2000), ECOSYS model (Metivier et al., 2009), and the RZWQM model (Shaffer et al., 2001). 75 Factors that affect the microbial growth rate in these models are the soil $\mathrm{N}$ and $\mathrm{C}$ content, soil 76 temperature, soil $\mathrm{pH}$ and soil moisture content. Microbial growth rates are assumed to be an estimate 77 of the $\mathrm{N}_{2} \mathrm{O}$ emission potential of a system that is higher microbial growth rates translate to higher $\mathrm{N}_{2} \mathrm{O}$ 78 emissions. The strength of these models is the representation of microbial growth and activity in the 79 model. This includes the number and type of microbes, the community structure and the death and 80 growth of microbes over time.

81 Soil structural models are based on soil physics and primarily consider the diffusion of gases and solutes 82 into and out of soil aggregates; these models use diffusion of gases and solutes as a proxy for the 83 anaerobic state, a primary control on $\mathrm{N}_{2} \mathrm{O}$ emissions (Heinen, 2006; Parton et al., 1996). $\mathrm{N}_{2} \mathrm{O}$ and 84 nutrients such as $\mathrm{NO}_{3}^{-}$and oxygen $\left(\mathrm{O}_{2}\right)$ are modeled moving into and out of soil aggregates. Soil 85 structural models include: the Steady State Denitrification model (Arah et al., 1989), which predicts 86 steady state denitrification rates as a function of soil moisture characteristics, aggregate soil particle 87 size, oxygen reduction potential, and $\mathrm{NO}_{3}{ }^{-}$concentration; the SLIM solute leaching model (Vinten et al., 88 1996), which simulates $\mathrm{N}_{2} \mathrm{O}$ emissions by considering the interaction between soil aggregates, soil 89 moisture and $\mathrm{O}_{2}$ diffusion; and methods described by Grant (1991), which uses a Michaelis-Menten 90 function to predict emissions based on the soil $\mathrm{NO}_{3}{ }^{-}$concentration. The strength of soil structural 91 models is that the anaerobic and aerobic condition of soil can be determined, resulting in the 92 identification of denitrification and nitrification stages and hotspots in a soil. These models are well 
suited to assessing fine scale $\mathrm{N}_{2} \mathrm{O}$ emissions (pore to plot scale), but require well-defined input data and/or calibration.

Physically-based, or integrated models, incorporate the relevant physical controls on $\mathrm{N}_{2} \mathrm{O}$ emissions by simulating interactions between plant, soil, hydrologic, management, and atmospheric factors to estimate $\mathrm{N}_{2} \mathrm{O}$ emissions. Kragt et al. (2011) and Kelly et al. (2013) suggest that integrated modeling (or integrated models) improve information transfer and decision-making by providing the ability to capture complex biological, chemical, and physical processes. Several of these integrated models exist, for example the DAYCENT (Del Grosso et al., 2002; Parton et al., 1998), DAISY (Hansen et al., 1991) and RZWQM2 models (Fang et al., 2015). These models incorporate soil parameters such as soil pH, soil temperature, soil moisture, and nutrients as driving forces controlling emissions. These models can be applied at fine or large scales with time steps of hourly to yearly and hotspots/hot moments on the landscape can be determined using these models. This class of models is generally considered the most robust and can be used outside of the range for which they were developed, unlike empirical models. This makes them ideally suited for various scenario analyses, such as assessing the impact of climate or land use change. Unfortunately, these models also require large amounts of data, some of which can be difficult to find.

In order to provide the ability to predict $\mathrm{N}_{2} \mathrm{O}$ emissions, we developed a new physically-based routine for the Soil and Water Assessment Tool model (SWAT), hereafter referred to as SWAT-GHG. Semidistributed, process-based models such as SWAT offer a promising platform on which to build GHG emission models because of detailed plant/crop and nutrient routines, relatively flexible hydrologic underpinnings and open source code. Indeed, recent coupling of SWAT with the biogeochemical model DAYCENT highlights the flexibility of SWAT (Wu et al., 2016). In addition, most of the parameters required to predict $\mathrm{N}_{2} \mathrm{O}$ emissions already exist in SWAT (total soil $\mathrm{C}$ and $\mathrm{N}, \mathrm{pH}$, temperature and precipitation), and SWAT has built in databases for plant and soil factors, so general model initialization requires very little additional data. The development of SWAT-GHG involved a two-part addition to SWAT: first, a set of reduction functions was developed to model the total denitrification $\left(\mathrm{N}_{2}+\mathrm{N}_{2} \mathrm{O}\right)$ and nitrification rates and second, a ratio method was applied to partition denitrification products $\mathrm{N}_{2}$ and $\mathrm{N}_{2} \mathrm{O}$. The new $\mathrm{N}_{2} \mathrm{O}$ routine was tested using plot data from the GRACEnet database in two locations: University Park, Pennsylvania, and West Lafayette, Indiana. A sensitivity analysis of total soil C and pH, N application, and climate forcing (temperature and precipitation) was performed to assess the sensitivity of the model to changes in input parameter values. We compared the predicted spatial distribution of 
$\mathrm{N}_{2} \mathrm{O}$ emission at the two sites with the field level measurements to assess the ability of SWAT-GHG to elucidate where and when hotspots of $\mathrm{N}_{2} \mathrm{O}$ production occur across agroecosystems.

\section{Materials and Methods}

127

Model Development: Here we describe the development of a new sub-model for SWAT, termed SWATGHG, to predict $\mathrm{N}_{2} \mathrm{O}$ emissions from agroecosystems. SWAT-GHG was developed by defining a set of reduction functions based on soil and environmental factors. The soil conditions include nutrient content $\left(\mathrm{NO}_{3}{ }^{-}, \mathrm{NH}_{4}{ }^{+}\right.$and total soil C) and soil $\mathrm{pH}$, while the environmental factors (precipitation and temperature) control the soil temperature and soil moisture conditions (Heinen, 2006; Morse et al., 2012; Weier et al., 1993). The reduction functions are based on work from Weier et al. (1993) and Parton et al. (2001) with adjustments made for the impact of soil pH and soil temperature.

SWAT Model Description: The SWAT model is a process-based, semi-distributed watershed model developed to predict the impact of land management on water availability and water quality (Arnold et al., 1998). SWAT requires weather, soil, land cover, and land management data to simulate surface and subsurface hydrology and various chemical, nutrient and sediment fluxes. SWAT-VSA re-conceptualizes SWAT to account for areas of the landscape subject to variable saturation dynamics (Easton et al., 2008). In SWTA-VSA the area of each hydrologic response unit (HRU) is defined by the coincidence of land use and wetness index class determined from a Topographic Index (TI) to differentiate areas of the landscape with respect to their moisture storage and saturation index (Easton et al., 2008). SWAT-VSA has been shown to provide better predictions of soil moisture and runoff generation than the standard SWAT model in watersheds with similar physical characteristics and climate to the study watersheds (Easton et al., 2008), and thus should provide a better platform to predict the spatial and temporal evolution of $\mathrm{N}_{2} \mathrm{O}$ emission hotspots.

SWAT was selected as the model to build on for several reasons: it is well documented, it is supported and available as open-source code, it has robust crop/plant simulation abilities, it contains numerous potential code linkage points, and recent improvements capture the spatial and temporal evolution of saturated areas of the landscape, which are known $\mathrm{N}_{2} \mathrm{O}$ emission hotspots (Groffman et al., 2009). Denitrification and nitrification processes are currently modeled in SWAT with first order reaction constants (e.g., denitrification only occurs above a threshold soil moisture content input by the user), but SWAT does not model $\mathrm{N}_{2} \mathrm{O}$ emissions from either process, predicting $\mathrm{N}_{2}$ as the only denitrification product. We incorporated the ability to predict $\mathrm{N}_{2} \mathrm{O}$ emissions by coupling the $\mathrm{C}$ and $\mathrm{N}$ cycles with soil 

moisture, $\mathrm{pH}$, and soil temperature by developing a denitrification subroutine "ndent_V2.f" and by modifying the existing nitrification and volatilization subroutine "nitvol.f" in SWAT. All of the parameters required to develop the routines [soil temperature, $\mathrm{pH}$, and nutrient content $\left(\mathrm{NH}_{4}{ }^{+}, \mathrm{NO}_{3}{ }^{-}, \mathrm{C}\right)$ ] are already incorporated in SWAT in various subroutines. Both subroutines predict $\mathrm{N}_{2} \mathrm{O}$ emission at the hydrologic HRU level (the smallest unit at which the model provides output and represents a unique combination land use and moisture index).

$160 \mathrm{~N}_{2} \mathrm{O}$ from denitrification was obtained by a two-part addition: (1) developing a set of equations to model 161 the total denitrification rate $\left(\mathrm{N}_{2}+\mathrm{N}_{2} \mathrm{O}\right)$ and (2) partitioning $\mathrm{N}_{2}$ from $\mathrm{N}_{2} \mathrm{O} \cdot \mathrm{N}_{2} \mathrm{O}$ from nitrification was 162 obtained by modifying the existing nitrification rate equation in SWAT and partitioning $\mathrm{N}_{2} \mathrm{O}$ from $\mathrm{NO}_{3}$.

163 The total denitrification flux from Parton et al. (1996) and Mosier et al. (2002) is:

$164 \quad D_{\text {Ntotal }}=\min \left[F d\left(\mathrm{NO}_{3}\right), \mathrm{Fd}(\mathrm{C})\right] * \mathrm{Fd}(\theta) * \mathrm{Fd}(\mathrm{T}) * \mathrm{Fd}(\mathrm{pH})$

165 where $D_{\text {Ntotal }}$ is the denitrification rate per unit area (production of $\left.\mathrm{N}_{2}+\mathrm{N}_{2} \mathrm{O}, \mathrm{g} \mathrm{N} \mathrm{ha}{ }^{-1} \mathrm{~d}^{-1}\right)$; $\mathrm{Fd}\left(\mathrm{NO}_{3}\right)$ is the maximum total $\mathrm{N}$ gas flux per unit area for a given soil $\mathrm{NO}_{3}{ }^{-}$level in $\mathrm{g} \mathrm{N} \mathrm{ha}^{-1} \mathrm{~d}^{-1}$ (assuming total soil $\mathrm{C}$ is not limiting); $\mathrm{Fd}(\mathrm{C})$ is the maximum total $\mathrm{N}$ gas flux per unit area for a given total soil $\mathrm{C}$ level in $\mathrm{g} \mathrm{N} \mathrm{ha}{ }^{-1} \mathrm{~d}^{-}$ ${ }^{1}$ (assuming soil $\mathrm{N}$ is not limiting); and $\mathrm{Fd}(\theta), \mathrm{Fd}(\mathrm{T})$, and $\mathrm{Fd}(\mathrm{pH})$ are functions that represent the effects of soil moisture, soil temperature, and $\mathrm{pH}$ on $\mathrm{N}$ gas flux, respectively. While the functional form of these relationships can differ to some extent, Parton et al. (1996) and Weier et al. (1993) have developed relatively robust functions for estimating $\mathrm{Fd}\left(\mathrm{NO}_{3}\right), \mathrm{Fd}(\mathrm{C})$, and $\mathrm{Fd}(\theta)$ :

$172 F d\left(\mathrm{NO}_{3}\right)=11,000+\frac{40,000+\operatorname{atan}\left(\pi * 0.002 *\left(\mathrm{NO}_{3}-180\right)\right)}{\pi}$

$173 F d(C)=\frac{24,000}{1+\frac{200}{e^{0.35 * C}}}-100$

$174 F d(\theta)=\frac{a}{b^{b^{(d * \theta)}}}$

175 where $\mathrm{Fd}\left(\mathrm{NO}_{3}\right)$ and $\mathrm{Fd}(\mathrm{C})$ have units of $\mathrm{g} \mathrm{N} \mathrm{ha}^{-1} \mathrm{~d}^{-1}, \theta$ is water-filled pore space in units of $\mathrm{m}^{3} \mathrm{~m}^{-3}, \mathrm{C}$ is the $176 \mathrm{C}$ content in $\mathrm{g} \mathrm{N} \mathrm{ha}^{-1} \mathrm{~d}^{-1}$, and a, b, c and d are soil-specific fitting parameters (Table 1 ) to incorporate the 177 effect of soil texture.

Table 1: Soil texture fitting parameters for denitrification rate model (Parton et al., 1996).

\begin{tabular}{|l|c|c|c|c|}
\hline Texture & a & b & c & d \\
\hline Sand & 1.56 & 12 & 16 & 2.01 \\
\hline
\end{tabular}




\begin{tabular}{|l|c|c|c|c|} 
Loam & 4.82 & 14 & 16 & 1.39 \\
\hline Clay & 60 & 18 & 22 & 1.06 \\
\hline
\end{tabular}

The soil temperature effect function, $\mathrm{Fd}(\mathrm{T})$, was derived from Seligman et al. (1981):

$183 \quad F d(T)=\operatorname{Max}\left[\left(0.9 * \frac{\text { Soil Temp }}{\text { Soil Temp }+\exp (9.93-0.312 * \text { Soil Temp })}+0.1\right), 0.1\right]$

184 The $\mathrm{pH}$ function, $\mathrm{Fd}(\mathrm{pH})$, was developed from Simek et al. (2002):

$185 \quad F d(p H)=\left\{\begin{array}{cl}0.001 & \text { for } p H \leq 3.5 \\ \frac{p H-3.5}{3} & \text { for } 3.5<p H<6.5 \\ 1 & \text { for } p H \geq 6.5\end{array}\right.$

186 We developed a ratio method to differentiate the $\mathrm{N}_{2} \mathrm{O}$ from $\mathrm{N}_{2}$ produced during denitrification:

$187 R_{N 2 / N 2 O}=\min \left[\operatorname{Fr}\left(\mathrm{NO}_{3}\right), \operatorname{Fr}(\mathrm{C})\right] * \operatorname{Fr}(\theta) * \operatorname{Fr}(\mathrm{pH})$

188 where $\mathrm{R}_{\mathrm{N} 2 / \mathrm{N} 2 \mathrm{O}}$ is ratio of $\mathrm{N}_{2}$ to $\mathrm{N}_{2} \mathrm{O}$, and $\mathrm{Fr}\left(\mathrm{NO}_{3}\right), \operatorname{Fr}(\mathrm{C}), \mathrm{Fr}(\theta)$ and $\mathrm{Fr}(\mathrm{pH})$ represent the effects of soil $\mathrm{NO}_{3}{ }^{-}$

$189-\mathrm{N}$, total soil $\mathrm{C}$, soil moisture, and $\mathrm{pH}$ on the ratio of $\mathrm{N}_{2}$ to $\mathrm{N}_{2} \mathrm{O}$, respectively. Note here that temperature 190 is not included in the ratio prediction as increasing temperature increases both $\mathrm{N}_{2}$ and $\mathrm{N}_{2} \mathrm{O}$ production 191 similarly (Parton et al. (1996). Again, functions from Parton et al. (1996) are adapted for $\operatorname{Fr}\left(\mathrm{NO}_{3}\right), \operatorname{Fr}(\mathrm{C})$, 192 and $\operatorname{Fr}(\theta)$, while $\operatorname{Fr}(\mathrm{pH})$ was modified from Dannenmann et al. (2008) and Rochester (2003).

$193 \operatorname{Fr}\left(\mathrm{NO}_{3}\right)=1-\left[0.5+\frac{1 * \operatorname{atan}\left(\pi * 0.01 *\left(\mathrm{NO}_{3}-190\right)\right.}{\pi}\right] * 25$

$194 \operatorname{Fr}(C)=13+\frac{30.78 * \operatorname{atan}(\pi * 0.07 *(C-13))}{\pi}$

$\operatorname{Fr}(\theta)=\frac{1.4}{13^{\frac{13}{(2.2 * \theta)}}}$

$196 \operatorname{Fr}(p H)=\frac{1}{1470 * e^{-1.1 * p H}}$

197 Total $\mathrm{N}_{2} \mathrm{O}$ production during denitrification is given by:

$198 \quad D N_{2} O=\frac{D t}{1+R_{N 2 / N 20}}$

199 where $\mathrm{DN}_{2} \mathrm{O}$ is total $\mathrm{N}_{2} \mathrm{O}$ flux per unit area in $\mathrm{g} \mathrm{N} \mathrm{ha}^{-1} \mathrm{~d}^{-1}$. 
$\mathrm{N}_{2} \mathrm{O}$ emissions from nitrification were obtained by modifying the existing nitrification routine in SWAT and developing a set of equations for partitioning $\mathrm{N}_{2} \mathrm{O}$ from $\mathrm{NO}_{3}{ }_{3}^{-}$. To calculate the total $\mathrm{N}_{2} \mathrm{O}$ flux from nitrification an equation from (Parton et al., 1998; Parton et al., 2001) is used:

$F_{N_{2} O}=F_{N o 3} * K_{2} * F_{\theta} * F_{T m p} * F_{p H}$

204 Where $F_{N_{2} O}$ is $\mathrm{N}_{2} \mathrm{O}$ flux from nitrification $\left(\mathrm{g} \mathrm{N} \mathrm{ha}^{-1} \mathrm{~d}^{-1}\right), \mathrm{K}_{2}$ is the fraction of nitrified $\mathrm{N}$ lost as $\mathrm{N}_{2} \mathrm{O}\left(\mathrm{K}_{2}\right.$ $205=0.02) . F_{N o 3}$ is the rate of nitrification, $F_{\theta}$ is the effect of soil water on nitrification, $F_{T m p}$ is the effect of 206 temperature, and $F_{p H}$ is the effect of soil $\mathrm{pH}$. Both $F_{N O 3}$ and $F_{\theta}$ are taken directly from SWAT.

207 The $F_{\mathrm{NO} 3}$ factor is given by:

$208 \quad F_{\text {NO3 }}=\frac{f_{\text {nit }}}{f_{\text {nit }}+f_{\text {vol }}} * N_{\text {nitvol }}$

209 Where $f_{\text {nit }}$ is the fraction of $\mathrm{N}$ lost to nitrification, $f_{v o l}$ is the fraction of $\mathrm{N}$ lost to volatilization and $210 N_{\text {nitvol }}\left(\mathrm{g} \mathrm{N} \mathrm{ha}^{-1} \mathrm{~d}^{-1}\right)$ is the amount of ammonium converted via nitrification and volatilization.

211 The $F_{\theta}$ factor is given by:

$212 \quad F_{\theta}=\frac{S W_{l y}-W P_{l y}}{0.25 *\left(F C_{l y}-W P_{l y}\right)}$ if $S W_{l y}<0.25 * F C_{l y}-0.75 * W P_{l y}$

$213 \quad F_{\theta}=1.0 \quad$ if $\quad S W_{l y} \geq 0.25 * F C_{l y}-0.75 * W P_{l y}$

214 Where $S W_{l y}$ is soil water content $(\mathrm{mm}), W P_{l y}$ is the amount of water held in the soil at wilting point 215 water content $(\mathrm{mm})$, and $F C_{l y}$ is amount of water held in the soil layer at field capacity water content $216(\mathrm{~mm})$.

217 The $F_{T m p}$ factor is given by:

$218 F_{T m p}=-0.06+0.13 * e^{(0.07 * \text { SoilTemp })}$

219 The $F_{p H}$ factor is given by:

$220 \quad F_{p H}=0.56+\frac{\arctan (\pi * 0.45 *(-5+\operatorname{soil} p H))}{\pi}$

221 The total $\mathrm{N}_{2} \mathrm{O}$ production from both denitrification and nitrification is given by:

$222 \quad \mathrm{~N}_{2} \mathrm{O}_{\mathrm{Total}}=D_{\mathrm{N}_{2} \mathrm{O}}+F_{\mathrm{N}_{2} \mathrm{O}}$

223 where $\mathrm{N}_{2} \mathrm{O}_{\text {Total }}$ is total $\mathrm{N}_{2} \mathrm{O}$ flux in $\mathrm{g} \mathrm{ha}^{-1} \mathrm{~d}^{-1}$.

224 Linking SWAT-GHG with SWAT Parameters: All of the variables described above are already defined in 225 SWAT and used in various other subroutines except for $\theta$. $\theta$ is calculated from the soil moisture 226 characteristics for each soil layer as the fraction of pore space occupied by water. Soil pH is included but 227 is inactive in SWAT code and is a user-defined input. Thus for model development we used a constant 
4228 soil $\mathrm{pH}$ over the user defined run time (note, however, that $\mathrm{pH}$ can be varied by the user during different 6229 model runs). In order to incorporate the impact of total soil $\mathrm{C}$ on $\mathrm{N}_{2} \mathrm{O}$ emissions, the new $\mathrm{N}_{2} \mathrm{O}$ routine utilizes one of two existing $C$ routines in SWAT. In the basins.bsn file in SWAT, users can select the original routine from SWAT (nminrl.f) or a modified C routine (C-Farm) developed by Kremanian et al. (2010). Note, the application that follows utilized the C-Farm routine.

Study Area: SWAT-GHG was tested using plot level data from agricultural watersheds in West Lafayette, Indiana (Fig.1a), and University Park, Pennsylvania (Fig. 1b). The watersheds have an area of $0.4 \mathrm{~km}^{2}$ (Fig.1a) and $0.6 \mathrm{~km}^{2}$ (Fig.1b), respectively. The crop types in University Park consist of corn, soybean, pasture and alfalfa, and West Lafayette crops consist of corn, soybean, sorghum and switchgrass. The soil type of the West Lafayette watershed is a loam, and the University Park watershed soil is a sandy clay loam.

239 Model Testing: SWAT-GHG was tested using data from the GRACEnet database 240 (http://nrrc.ars.usda.gov/arsdataportal/ - /Home) at two locations: (1) University Park, Pennsylvania, 241 and (2) West Lafayette, Indiana. SWAT-VSA (SWAT-Variable Source Area, Easton et al., 2008) was used 242 for model testing. SWAT-VSA was initialized for both locations based on field level input data from the 243 GRACEnet database to force the model where available. SWAT-VSA provided the soil moisture and 244 temperature time series for the new routine, and all other inputs were taken from the GRACEnet 245 database if available (soil properties) or left as default if unavailable (pH). In order to better understand 246 which parameters had the largest effect on $\mathrm{N}_{2} \mathrm{O}$ emissions we conducted a sensitivity analysis on $\mathrm{N}$ 247 application rate, total soil $\mathrm{C}, \mathrm{pH}, \theta$ and soil temperature. 


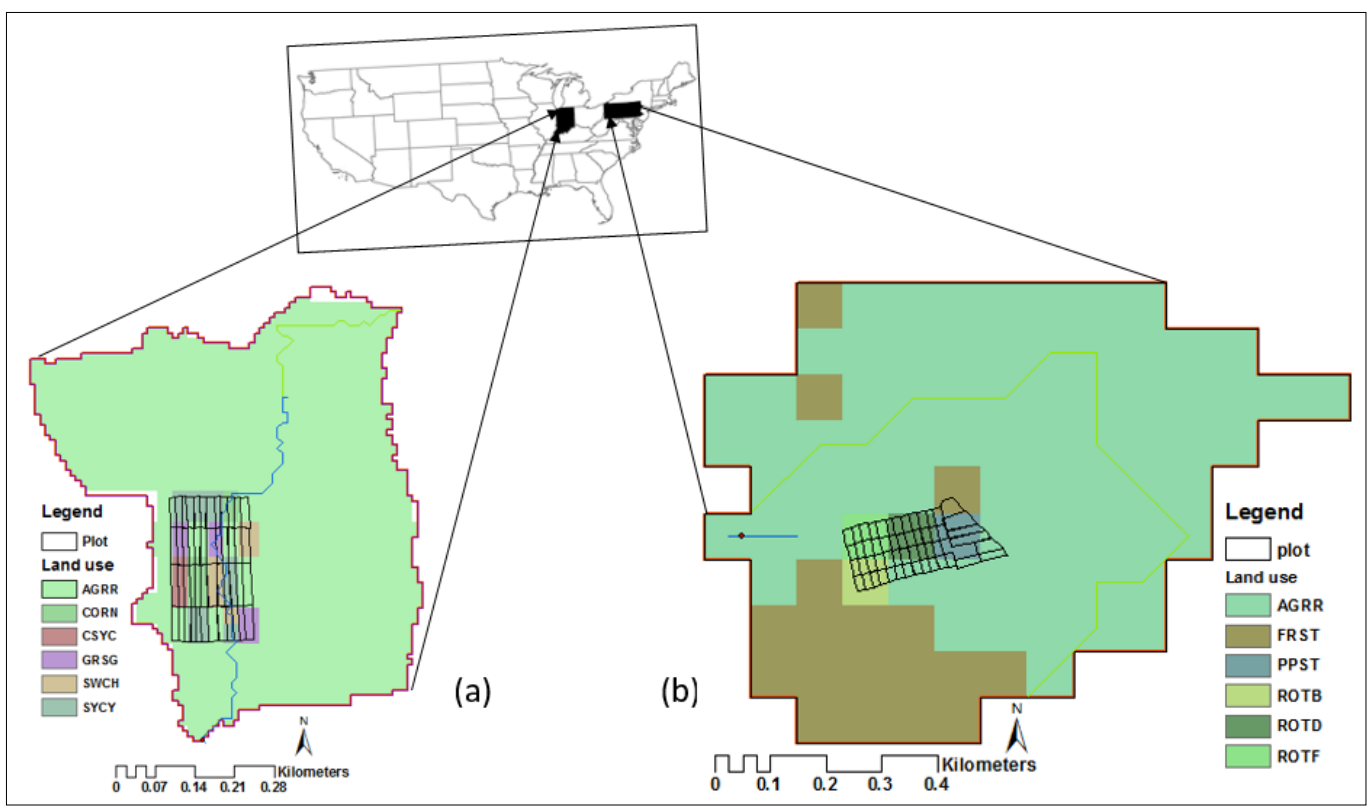

250

Figure 1: (a) West Lafayette, IN, watershed and GRACEnet site with land uses AGRR (Agriculture); Corn; CSYC (Corn-Soybean-Corn crop rotation); GRSG (Sorghum); SWCH (Switchgrass); SYCY (Soybean-CornSoybean crop rotation) and (b) University Park, PA, watershed and GRACEnet site with land uses AGRR (Agriculture); FRST (Forest); PPST Pasture); ROTB (Soybean rotation); ROTD (Alfalfa rotation); ROTF (Corn rotation).

Model Initialization: SWAT-VSA was initialized for University Park and West Lafayette sites using ArcSWAT 2012 and TopoSWAT (available from http://ww2.bse.vt.edu/eastonlab/). TopoSWAT automates the SWAT-VSA initialization process by assimilating soil data, creating the TI map, overlaying the soil and TI maps, and developing the required database for model initialization (Fuka et al., 2016). Soils data included in TopoSWAT is based on Food and Agriculture Organization (FAO) soils database (FAO 2007). The FAO soils were used as the base map and parameters (total soil $\mathrm{C}$ and $\mathrm{N}$, soil texture) were adjusted using data provided in the GRACEnet database for each site. The land use input for both watersheds was obtained by first digitizing plot level land use based on the crop rotation of plots in the GRACEnet database. Digitized plot level land use data was then cross-referenced with data from the National Land Cover database (NLCD 2011). The use of the NLDC was required because GRACEnet did not have all of the SWAT required soil, management, or plant growth and development parameters needed to run the model. A digital elevation model (DEM) with $10 \mathrm{~m}$ resolution from the United States Geologic Survey (USGS) National Elevation Dataset (NED) (Guenther et al., 2007) was used for both locations. The final initialization resulted in one subbasin with 58 HRUs for West Lafayette and one subbasin with $21 \mathrm{HRUs}$ for University Park. Weather data from the GRACEnet database, including daily precipitation and temperature ( $\min$ and $\max$ ) from 2004 to 2013, was used to force the model. Soil 
properties such as organic $\mathrm{C}$ content (\%), soil $\mathrm{NO}_{3}{ }^{-}$content $\left(\mathrm{mg} \mathrm{kg}^{-1}\right)$ and a default $\mathrm{pH}$ value of 6.5 from the FAO database were used to initialize both models.

GRACEnet Database: GRACEnet (Greenhouse gas Reduction through Agricultural Carbon Enhancement network) is research program initiated by USDA Agricultural Research Service (ARS) to build high-quality data on trace gas fluxes in agroecosystems (Del Grosso et al., 2013). GRACEnet provides a site description, measured greenhouse gas fluxes, soil carbon levels, biomass yield, soil nutrient content, planting date, and fertilizer application rate, type and amount. Emission data are provided at a daily scale when measured, but measurements are periodic (e.g., measurements are made weekly). Thus we extract the model predicted fluxes on days that measurements are made for comparison. The spatial resolution is plot level, and measurements are made using the static chamber method where two chamber replicates are used per plot; detailed information about GRACEnet data can be found http://nrrc.ars.usda.gov/arsdataportal/\#/Home.

Model Calibration: There are many different methods to calibrate the SWAT model including genetic approaches, directional searches and evolutionary optimization (Zhang et al., 2016). However, given the complex crop rotations at the sites and the new variables introduced in SWAT-GHG both models were manually calibrated to the observed $\mathrm{N}_{2} \mathrm{O}$ flux by changing the total soil $\mathrm{C}$ content in the first and second soil layers (as defined in the soils database), the amount and timing of $\mathrm{N}$ application ${ }^{-}$in the management file, and the soil $\mathrm{pH}$. Soil moisture and soil temperature were not used in the calibration since they were explicitly known and controlled by the measured precipitation and temperature.

Model Corroboration: After manual calibration of both models, model performance was verified using subsequent time series data from 2011 to 2012 for West Lafayette and 2008 for University Park for respective crop types. Since the GRACEnet plots were managed under specific rotations, we corroborated both models by matching the crop rotation in the SWAT management files for those crop types that coincided between the calibration and corroboration time periods. Since there were multiple plots at each site managed under the same rotation (e.g., corn-soy) but at various stages in the rotation (e.g., one plot in the corn-soy rotation might be under corn in 2006 and another plot might be under soy), we extracted the modeled and observed $\mathrm{N}_{2} \mathrm{O}$ fluxes that corresponded with each specific crop type by year and averaged the plot values together to create the time series of fluxes. As an example, in West Lafayette for the corn-soy rotation, the measured data started in 2008 and plot 1 was under soy, plot 2 was under corn and plot 3 was under soy, etc., so for 2008 soy fluxes consisted of measured and 
modeled data for plots 1 and 3 (averaged together), and corn for plot 2. In this manner, we iterated through each year sequentially extracting plot by crop fluxes to develop the time series of flux data. For each rotation year in the SWAT management file, where crop rotations are defined, we kept all calibrated parameters associated with each crop the same but changed the planting date and fertilizer application date according to the GRACEnet database and then reran the model.

There are many different model performance metrics available to test model skill (Bennett et al., 2013). Among different quantitative methods, the coefficient of determination $\left(r^{2}\right)$, Nash and Sutcliffe (1970) efficiency coefficient (NSE) are perhaps the most common (Moriasi et al., 2015), but both tend to evaluate the model skill in capturing the mean response. Since the extreme $\mathrm{N}_{2} \mathrm{O}$ fluxes are of greater environmental importance, we include a performance metric that describe model performance of the extremes, namely the absolute maximum error (AME) (Bennett et al., 2013). The AME is a metric that indicates the maximum absolute deviation in the time series between measured and modeled data. Thus, the model skill was evaluated by comparing time series of simulated $\mathrm{N}_{2} \mathrm{O}$ flux with observed $\mathrm{N}_{2} \mathrm{O}$ flux data from the GRACEnet database and by comparing the predicted spatial distribution of emissions at the $\mathrm{HRU}$ level with the plot level $\mathrm{N}_{2} \mathrm{O}$ emissions measured at each site.

Model Sensitivity Analysis (SA): A model sensitivity analysis was performed on each model by altering the initial conditions of the input parameters, including total soil $\mathrm{C}, \mathrm{N}$ application rate, soil $\mathrm{pH}$, air temperature (which subsequently alters soil temperature), and precipitation (which subsequently alters $\theta$ ) by manually changing one variable at a time while keeping others unchanged (Norton, 2015; Pianosi et al., 2016; Saltelli et al., 2010). Manual SA was chosen for several reasons 1) the relatively few number of HRUs and parameters of interest facilitated manual parameter adjustment and; 2 ) the most sensitive parameters can be easily identified. The SA was conducted by directly increasing or decreasing the $\mathrm{C}$ content by $10 \%, 20 \%$, and $50 \%$ from the base model total soil $\mathrm{C}$ level, which resulted in a range of $\mathrm{C}$ contents typically found in agricultural soils for the two regions $(0.6 \%-1.7 \%$ total soil $\mathrm{C})$. In contrast, the soil $\mathrm{N}$ content was changed by increasing or decreasing the applied $\mathrm{N}$ (fertilizer application rate) in the management file by $10 \%, 20 \%$, and $50 \%$ relative to the base model, which in turn altered the soil $\mathrm{N}$ level

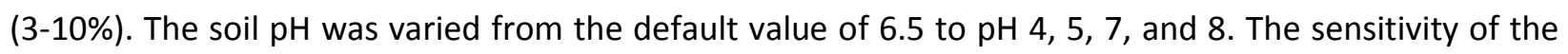
model to soil temperature and $\theta$ was assessed by increasing or decreasing the air temperature and precipitation, respectively, by $10 \%, 20 \%$, and $30 \%$, as the $+/-50 \%$ adjustment was deemed outside the range of plausible conditions. A joint SA was calculated for applied $\mathrm{N}$ and $\mathrm{pH}$ as the model was shown to be most sensitive to their input. 


\section{Results}

Sensitivity Analysis: Model sensitivities were similar across all crop types; thus, we present SA results for the corn land use at both sites. Figure 2 shows the results of the $\mathrm{SA}$ on $\mathrm{N}_{2} \mathrm{O}$ and $\mathrm{N}_{2}$ emissions for the University Park and West Lafayette sites. Both models were very sensitive to $\mathrm{pH}$ and applied $\mathrm{N}$, moderately sensitive to soil temperature and precipitation, and relatively insensitive to total soil $\mathrm{C}$ content. At University Park, $\mathrm{N}_{2} \mathrm{O}$ emissions increased by 65 and $46 \%$ as the $\mathrm{pH}$ was lowered from the base condition of 6.5 to 5 and 4, respectively, while emissions declined by 34 and $74 \%$ when the pH was raised from 6.5 to 7 and 8, respectively. At West Lafayette, $\mathrm{N}_{2} \mathrm{O}$ emissions increased by $11 \%$ at pH 5, but decreased by $11 \%, 38 \%$, and $70 \%$ at $\mathrm{pH} 4,7$, and 8 , respectively. The model was also sensitive to the $\mathrm{N}$ application rate; higher $\mathrm{N}$ application rates resulted in higher $\mathrm{N}_{2} \mathrm{O}$ emissions, up to $130 \%$ at University Park and $94 \%$ at West Lafayette when $\mathrm{N}$ application was increased by $50 \%$, while decreases in $\mathrm{N}$ application rates reduced $\mathrm{N}_{2} \mathrm{O}$ emissions by as much as $76 \%$ at University Park and $77 \%$ at West Lafayette when $\mathrm{N}$ application was decreased by $50 \%$ (Fig. 2). At the University Park site increasing temperature by $10 \%$ and $20 \%$ resulted in small increases in emissions (1-6\%), while a $30 \%$ temperature increase reduced emissions by $1 \%$. At West Lafayette decreasing temperature increased emissions (327\%) while increasing temperature decreased emissions (15-18\%). At University Park increases in precipitation decreased $\mathrm{N}_{2} \mathrm{O}$ emissions slightly, 2-9\%, while decreases in precipitation increased emissions $4-11 \%$ (Fig. 2). At West Lafayette both increase and decreases in precipitation tended to reduce emissions (1-15\%). At both sites, increases in total soil $\mathrm{C}$ tended to increase $\mathrm{N}_{2} \mathrm{O}$ emissions, while decreases in total soil $\mathrm{C}$ reduce $\mathrm{N}_{2} \mathrm{O}$ emissions, although the magnitude of the changes was small ( $\leq 7 \%$ ).

$\underline{\mathrm{N}}_{2} \mathrm{O}$ to $\mathrm{N}_{2}$ Comparison: Figures $2 \mathrm{a}$ and $\mathrm{b}$ show the breakdown of the modeled total daily denitrification products $\left(\mathrm{N}_{2} \mathrm{O}\right.$ and $\left.\mathrm{N}_{2}\right)$ at University Park site and West Lafayette, respectively for each level of the parameters tested in the SA. Since the model results were found to be particularly sensitive to $\mathrm{pH}$ and applied $\mathrm{N}$ we present the results of a multi-level SA (Figs. 3a and b). In this analysis we varied applied $\mathrm{N}$ and $\mathrm{pH}$ together. Figures $3 \mathrm{a}$ and $\mathrm{b}$ illustrate that increasing the soil $\mathrm{pH}$ while simultaneously increasing the soil $\mathrm{N}$ content dramatically increases the total denitrification rate and decreases the $\mathrm{N}_{2} \mathrm{O}: \mathrm{N}_{2}$ product ratio. These figures demonstrate that, like $\mathrm{N}_{2} \mathrm{O}$ emissions, both total denitrification and the ratio of denitrification products are most sensitive to $\mathrm{pH}$ followed by $\mathrm{N}$ application rate, and highlight the importance of both total flux and the product ratio in driving the differences in $\mathrm{N}_{2} \mathrm{O}$ emissions presented in Figure 2. For example, Figures $2 \mathrm{a}$ and $\mathrm{b}$ show that $\mathrm{as} \mathrm{pH}$ increases total denitrification increases and the ratio $\mathrm{N}_{2} \mathrm{O}: \mathrm{N}_{2}$ decreases. One exception to this is the lower level of denitrification observed at the 
4362 University Park site at pH 7 compared to 8. While low pH is associated with higher $\mathrm{N}_{2} \mathrm{O}$ emissions and 6363 higher ratio between $\mathrm{N}_{2} \mathrm{O}: \mathrm{N}_{2}$ (Figs. 3a and b), the lower emissions predicted at $\mathrm{pH} 4$ relative to pH 5 at 8364 both sites are driven by the decrease in total denitrification, which overwhelms the ratio effect, and 365 limits $\mathrm{N}_{2} \mathrm{O}$ flux at $\mathrm{pH}$ 4. After $\mathrm{pH}, \mathrm{N}$ application rate has the greatest effect not only on $\mathrm{N}_{2} \mathrm{O}$ emissions, 366 but also on total denitrification flux. The relationship between $\mathrm{pH}$ and total denitrification and $\mathrm{N}_{2} \mathrm{O}$ 367 production is the same at both sites, as well as the effect of soil $\mathrm{N}$ content as expected. Both sites 368 demonstrate the expected correlation, where total denitrification, $\mathrm{N}_{2} \mathrm{O}: \mathrm{N}_{2}$, and $\mathrm{N}_{2} \mathrm{O}$ emissions increase 369 as soil $\mathrm{N}$ content increases. Temperature increases tended to reduce $\mathrm{N}_{2} \mathrm{O}$ emissions at both sites but 370 there was no clear impact on $\mathrm{N}_{2}$ or the product ratio due to changing temperature. Increasing or 371 decreasing total soil $\mathrm{C}$ or precipitation had little effect on denitrification emissions or the product ratio 

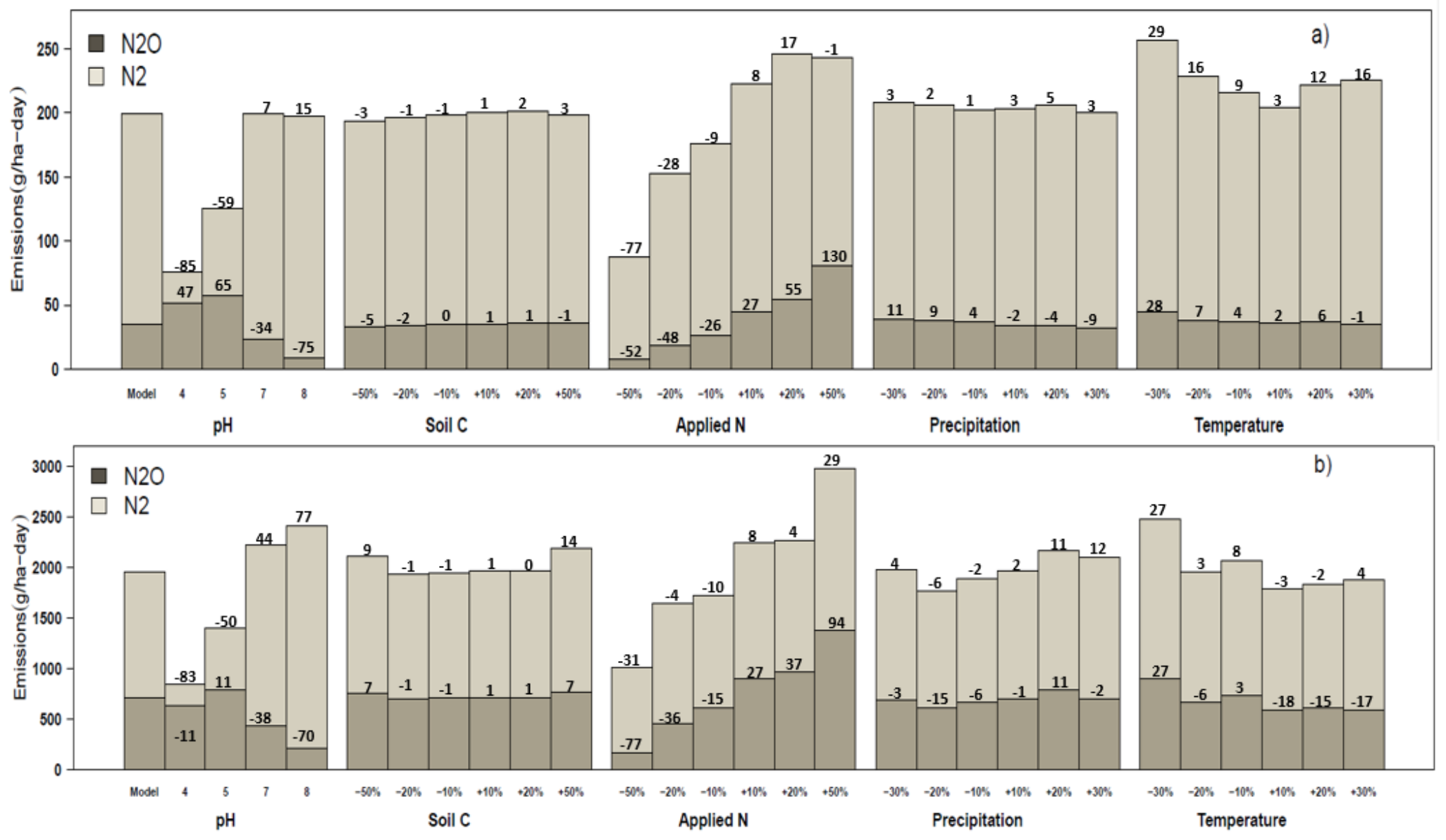

Figure 2:

Figure 2. Comparison of model output $\mathrm{N}_{2} \mathrm{O}$ and $\mathrm{N}_{2}$ (from both nitrification and denitrification) for different soil and environmental factors and percent change (over each bar) from the base model ${ }^{1}$ at the University Park site (a) and the West Lafayette site (b) for the corn land use.

${ }^{1}$ The base model parameter values for the University Park site are: $\mathrm{pH}=6.5$, total soil $\mathrm{C} \%=1.7$ for the first soil layer and 0.7 for the second soil layer; mean temperature $=10^{\circ} \mathrm{C}$, mean yearly precipitation $=1035 \mathrm{~mm}$, and soil $\mathrm{N}=650 \mathrm{~kg} / \mathrm{ha}$. The initial model parameters for West Lafayette site are: $\mathrm{pH}=6.5$, total soil $\mathrm{C} \%=1.6$ for the first soil layer and 0.7 for the second soil layer, mean daily temperature $=11.8^{\circ} \mathrm{C}$, mean yearly precipitation $=1174 \mathrm{~mm}$, and soil $\mathrm{N}=1800 \mathrm{~kg} / \mathrm{ha}$. 


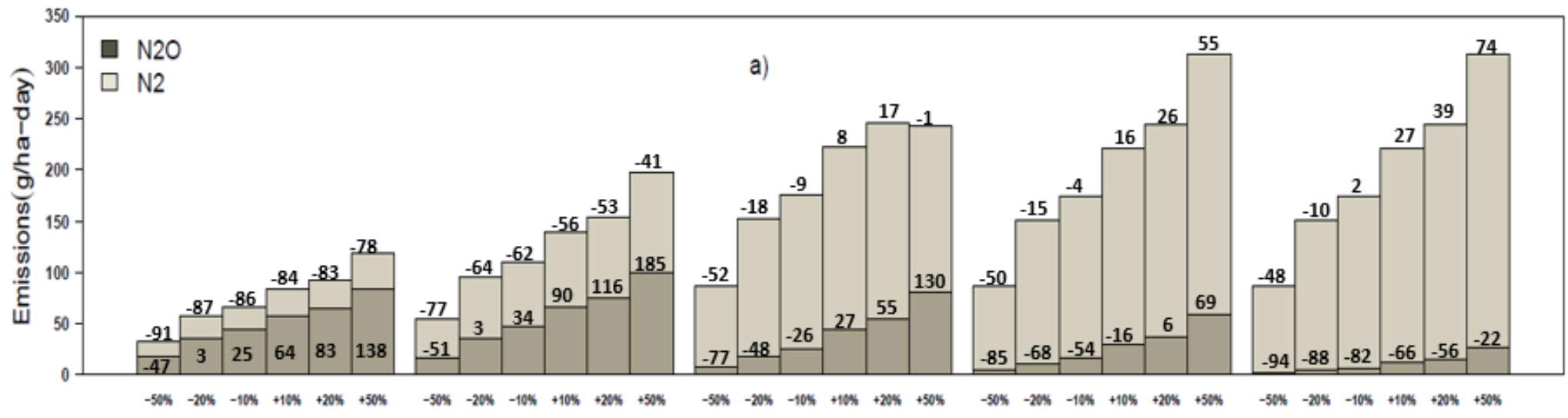

pH 4

pH 5 .

pH 6.5

Applied N

pH 7

pH 8

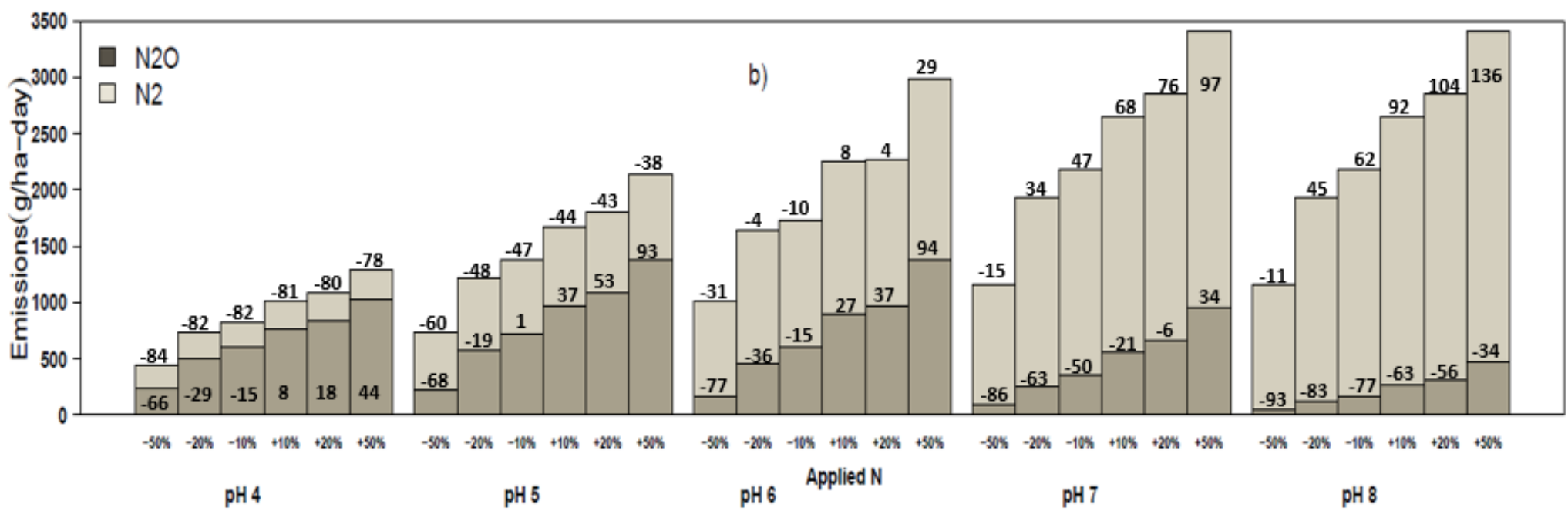

Figure 3: Comparison of model output $\mathrm{N}_{2} \mathrm{O}$ and $\mathrm{N}_{2}$ (from both nitrification and denitrification) and percent change (over each bar) against the base model in Figure 2 for simultaneous changes in applied $\mathrm{N}$ and pH at the University Park site (a) and the West Lafayette site (b) for the corn land use 
Model Corroboration: Table 2 shows the NSE, $\mathrm{R}^{2}$, and AME of the measured versus calibrated and corroborated model $\mathrm{N}_{2} \mathrm{O}$ emissions for different crops at both test sites. The NSE values shows the model has good mean explanatory power for all crops at both test sites during the calibration period, with slightly lower, but still acceptable predictive power during the corroboration period. In terms of peak model prediction there is more variability; the model captures peak $\mathrm{N}_{2} \mathrm{O}$ emissions generally well at both sites, but the AME indicated some peak error, some of which is due to mistimed peaks (e.g., corn at both sites) and some is due to under or over predicted peaks (e.g., soy at University Park, sorghum at West Lafayette, Figs. 4 and 6). Comparing each crop, the model predicted $\mathrm{N}_{2} \mathrm{O}$ emissions best, as 395 indicated by NSE value, for alfalfa followed by corn, soybean and pasture at University Park, and sorghum, followed by corn and soybean at West Lafayette. There was some reduced model performance during the corroboration periods at both sites, which is primarily due to averaging responses of different plots into one time series. Despite this, the models captured the timing and magnitude of $\mathrm{N}_{2} \mathrm{O}$ emissions relatively well.

Table 2: R-squared values $\left(R^{2}\right)$, Nash-Sutcliffe coefficients (NSE), and absolute maximum error (AME) and for the calibrated model for all crop types at both test sites, University Park and West Lafayette. Note that the variables that were calibrated were the soil $\mathrm{pH}, \mathrm{N}$ application rate, and total soil $\mathrm{C}$ level, and all others remained as defaults from the GRACEnet database or SWAT initialization.

\begin{tabular}{|c|c|c|c|c|c|c|c|}
\hline \multirow{2}{*}{ Site } & \multirow{2}{*}{ Crop } & \multicolumn{3}{|c|}{ Calibration } & \multicolumn{3}{|c|}{ Corroboration } \\
\hline & & $\mathrm{R}^{2}$ & NSE & AME & $\mathrm{R}^{2}$ & NSE & AME \\
\hline \multirow{4}{*}{ 旁 } & Corn & 0.67 & 0.65 & 95.0 & 0.51 & 0.44 & 45.2 \\
\hline & Alfalfa & 0.95 & 0.86 & 9.0 & 0.48 & 0.42 & 26.0 \\
\hline & Soybean & 0.81 & 0.56 & 39.2 & 0.42 & 0.24 & 95.7 \\
\hline & Pasture & 0.52 & 0.51 & 51.6 & 0.60 & 0.51 & 39.3 \\
\hline \multirow{3}{*}{ 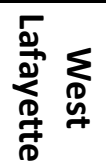 } & Corn & 0.74 & 0.73 & 2953.7 & 0.70 & 0.41 & 2765.6 \\
\hline & Soybean & 0.69 & 0.48 & 299.5 & 0.73 & 0.34 & 116.5 \\
\hline & Sorghum & 0.80 & 0.78 & 426.8 & 0.48 & 0.44 & 309.7 \\
\hline
\end{tabular}




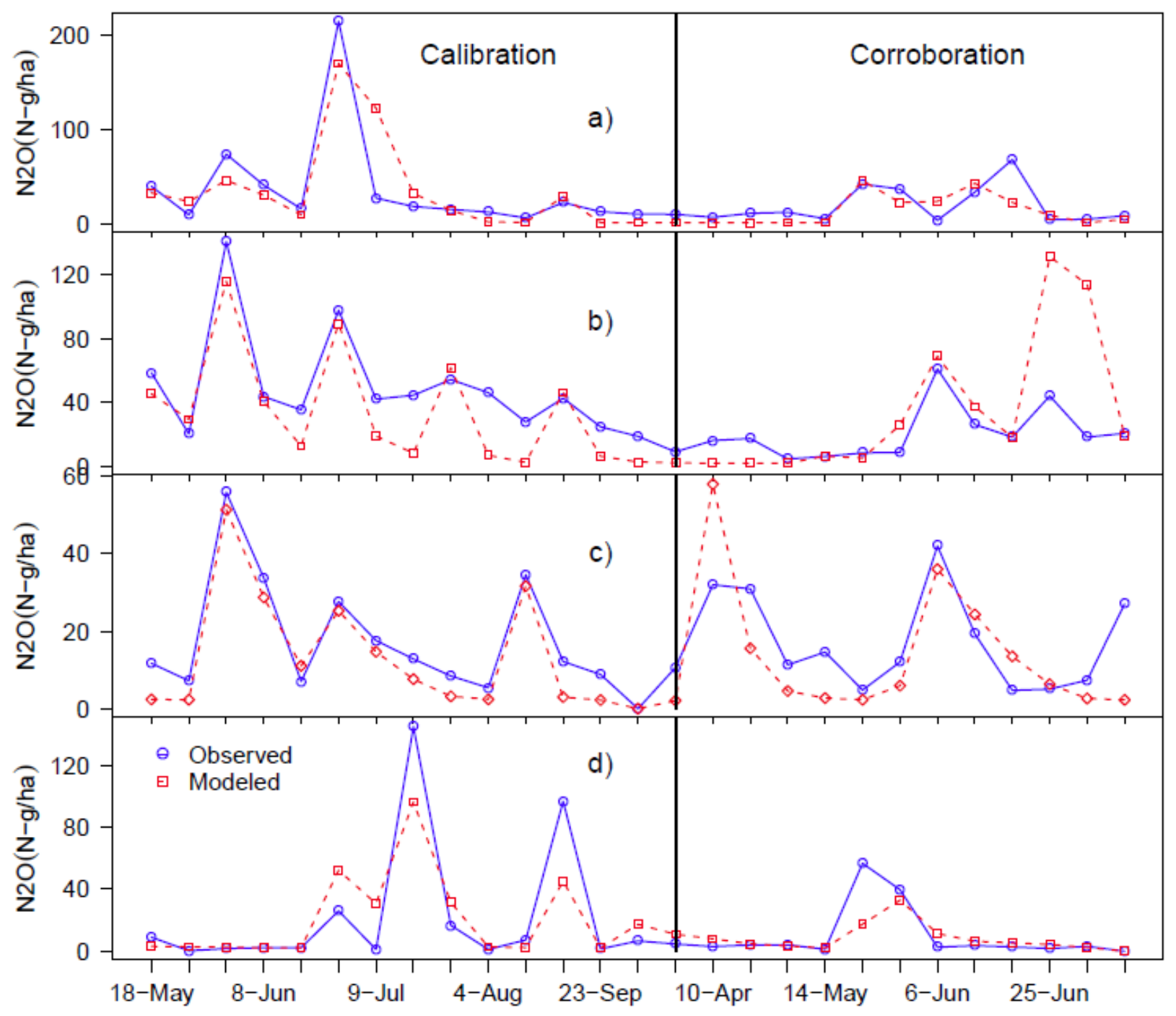

408 Figure 4: Comparison of observed and modeled $\mathrm{N}_{2} \mathrm{O}$ emissions for the University Park site for 2006 during calibration and 2008 for corroboration; (a) Corn, (b) Soybean, (c) Alfalfa, and (d) Pasture

University Park, PA

411 Time Series Evaluation: The time series of measured and modeled $\mathrm{N}_{2} \mathrm{O}$ emissions were compared for 412 each crop type at the University Park site. The comparison between observed and simulated $\mathrm{N}_{2} \mathrm{O}$ 413 emissions for the corn crop (Fig. 4a) shows that the model captured both the magnitude and timing of 415 calibration period the model predicted the seasonal pattern of $\mathrm{N}_{2} \mathrm{O}$ moderately well with a slight under 416 estimation during July-September, although the peaks are well predicted (Fig. 4b). During the 417 corroboration period the timing of emission peaks is well captured, but the June event is over predicted 418 (Fig. 4b). For alfalfa the model predicted both the timing and peak values well during the calibration period, particularly following the fertilizer applications in May, June, and August (Fig. 4c). During the 
corroboration period emission timing was well captured, but the event in April was over predicted (Fig. 4c). For pasture (Fig. 4d) in both the calibration and corroboration periods the model tended to under estimate the peaks but captured the timing and lower emissions well.

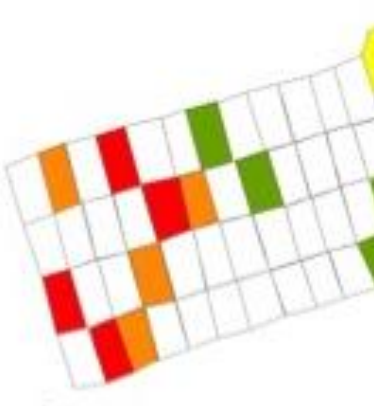

a) Mean Daily $\mathrm{N}_{2}$ O Flux ( $\mathrm{g} \mathrm{ha}^{-1}$ )

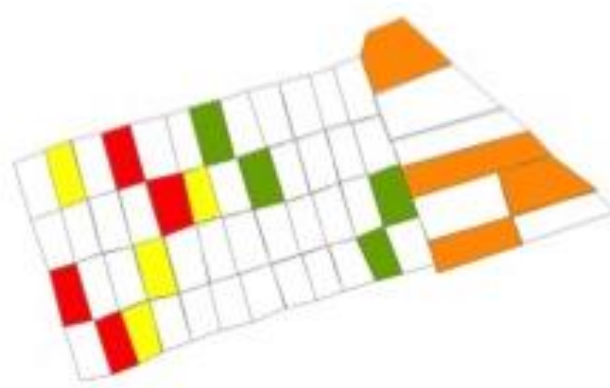

b)
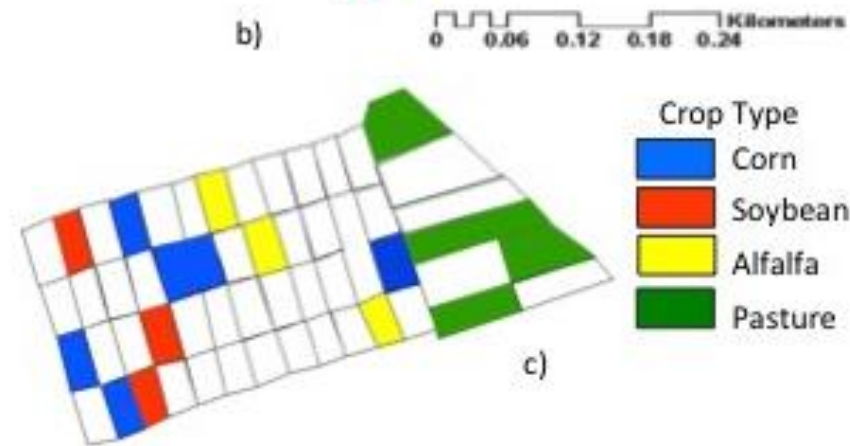

Crop Type

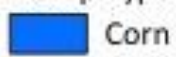

Soybean

Alfalfa

Pasture
423

424 425 426 427 428 429 430 431 432 433 434 436 437 438 439 440 (1) (2) (2)

Figure 5: Spatial comparison of daily average $\mathrm{N}_{2} \mathrm{O}$ emissions for the University Park site for 2008, ((a) measured $\mathrm{N}_{2} \mathrm{O}$ flux, (b) modeled $\mathrm{N}_{2} \mathrm{O}$ flux, (c) crop types where measurements were made. The overlay polygon map shows the field layout for the site. Unpredicted plots are those for which GRACEnet $\mathrm{N}_{2} \mathrm{O}$ measurements were unavailable, where we could not match the rotations or the crop type did not exist in the SWAT crop database.

Spatial Evaluation: Figure 5 shows the measured and predicted spatial distribution of $\mathrm{N}_{2} \mathrm{O}$ emissions for the University Park site. In general, the model was able to predict the distribution of emission well, both spatially and in magnitude. The model tended to slightly over predict emissions from pasture (by about $15 \%)$, but corn, alfalfa, and soybean emissions were well predicted across the site, with less than a $10 \%$ difference (Fig. 5).

\section{West Lafayette, IN}

Time Series Evaluation: The time series evaluation between observed and simulated $\mathrm{N}_{2} \mathrm{O}$ emissions for different crop types examines 2008 to 2010 for the calibration period and 2011 for the corroboration period. For corn, the model captured the magnitude of the peaks quite well during the calibration period, despite missing the timing of the peaks slightly in June 2008 and 2010 (Fig. 6a). During the corroboration period the event timing was well predicted but the magnitude was slightly under predicted (Fig. 6a). Emissions from the soybean crop (Fig. 6b) were well predicted during the calibration 
and corroboration periods. Figure $6 \mathrm{c}$ shows model predicted $\mathrm{N}_{2} \mathrm{O}$ emissions for sorghum and that it was able capture the seasonal pattern of emissions, despite some underestimated peaks in both the calibration and corroboration periods.

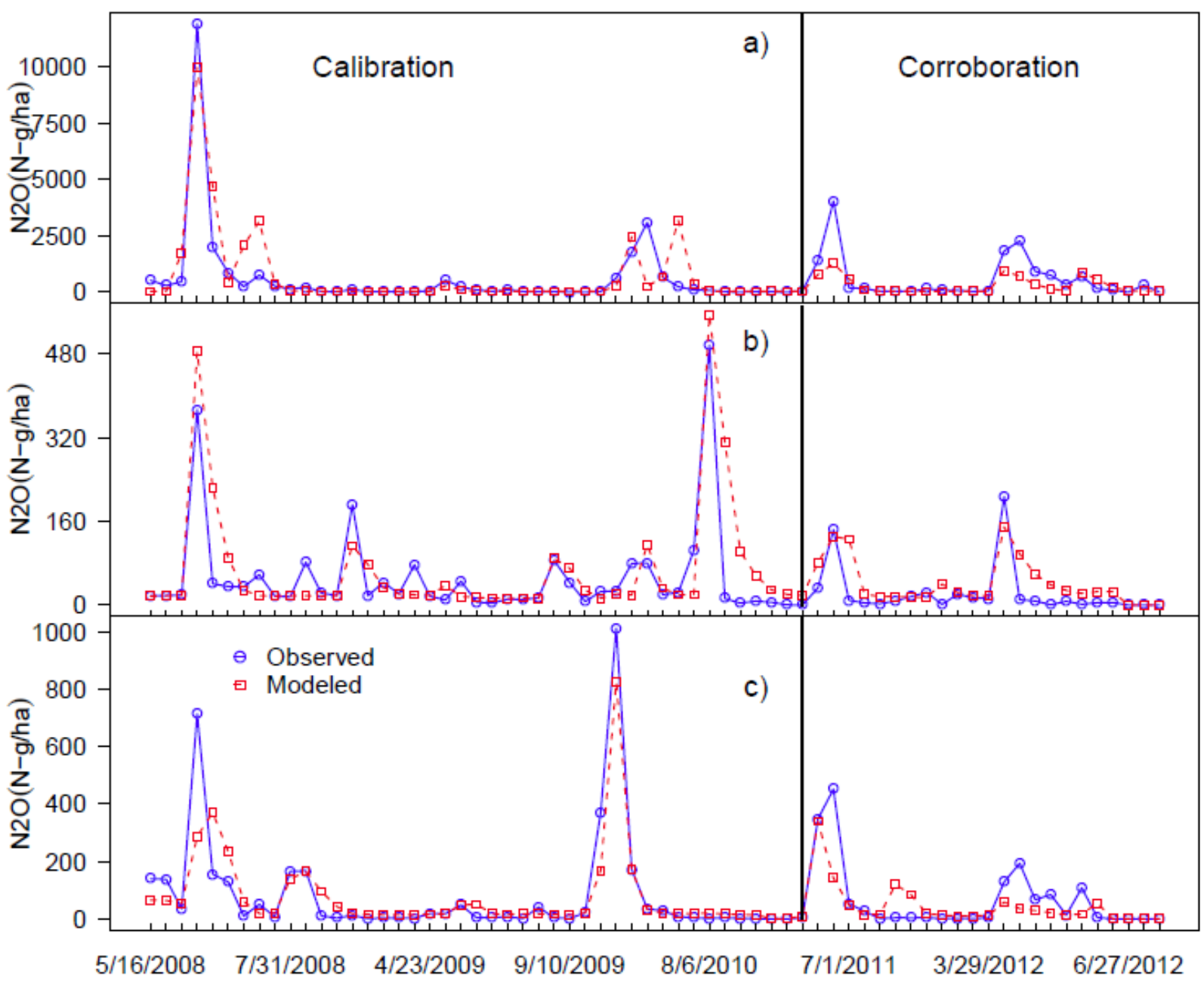

Figure 6: Comparison of observed and modeled $\mathrm{N}_{2} \mathrm{O}$ emissions for West Lafayette, 2008 to 2010 for calibration and 2011 to 2012 for corroboration for (a) Corn, (b) Soybean, and c) Sorghum.

448 Spatial Evaluation: Figure 7 shows the measured and predicted spatial distribution of $\mathrm{N}_{2} \mathrm{O}$ emissions for the West Lafayette site. Similar to the University Park site the model generally predicted both the spatial distribution and magnitudes of emission well across the fields (Fig. 7). The corn and corn-soybean rotation were slightly more accurately predicted than the sorghum crop. The West Lafayette site 452 exhibited variability between crop types and between plots than at University Park, which the model is 453 able to capture. For instance, corn had measured emissions ranging from $<5$ to $50 \mathrm{~g} \mathrm{ha}^{-1}$ at West 


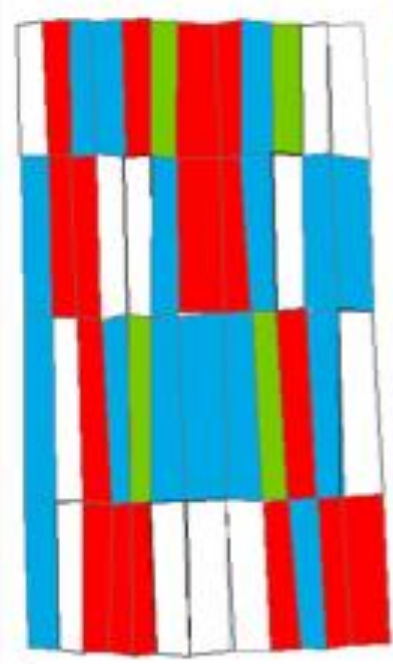

a) Crop Type \begin{tabular}{ll}
\hline & Corn \\
\hline & Soybean \\
& Sorghum
\end{tabular}

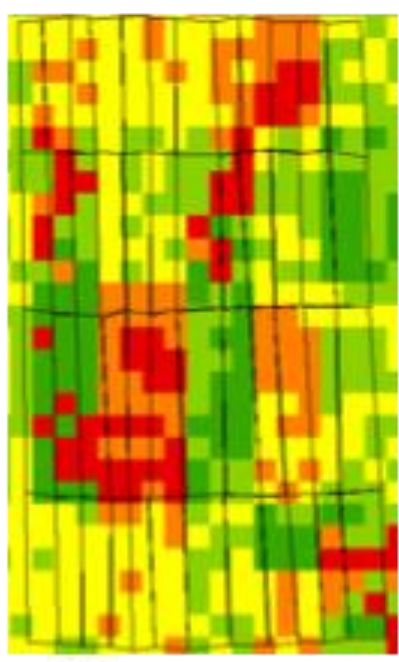

b)

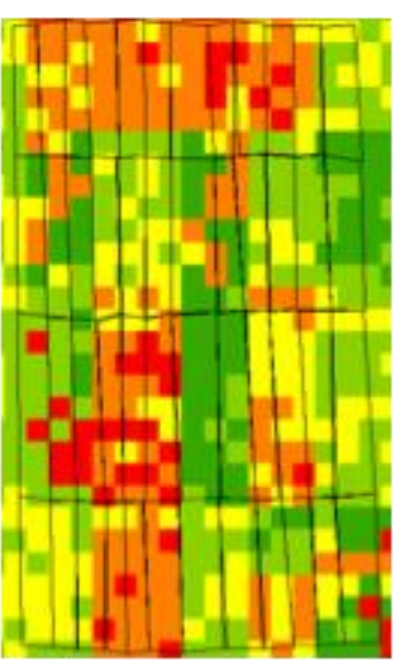

Mean Daily $\mathrm{N}_{2} \mathrm{O}$ Flux ( $\mathrm{g}$ ha' ${ }^{-1}$ )

\begin{tabular}{|c|}
\hline $39.3-50.0$ \\
\hline $33.7-39.2$ \\
\hline $8.1-33.6$ \\
\hline $5.1-8.1$ \\
\hline $0-5.0$ \\
\hline
\end{tabular}

c)

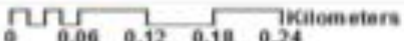

Figure 7: Spatial comparison of daily average $\mathrm{N}_{2} \mathrm{O}$ emissions for West Lafayette test site for 2011, (a) measured $\mathrm{N}_{2} \mathrm{O}$ flux, (b) modeled $\mathrm{N}_{2} \mathrm{O}$ flux, (c) crop types where measurements were made. Unpredicted plots are those for which GRACEnet $\mathrm{N}_{2} \mathrm{O}$ measurements were unavailable, rotations could not be matched or the crop type did not exist in SWAT. Note that multiple HRUs can occur in a single field due to differences in soil type and topography.

\section{Discussion}

\section{Modeling the Environmental Controls on $\mathrm{N}_{2}=\underline{O}$ and $\mathrm{N}_{2}$ Emissions}

$\underline{p H}: \mathrm{N}_{2} \mathrm{O}$ emissions were by far the most sensitive to changes in $\mathrm{pH}$ (Figs. 2 and 3 ), and it is reassuring that the model was able to capture this effect because $\mathrm{pH}$ has long been known to exert both proximal and distal control on emissions (Mørkved et al., 2007). Some of this effect is due to the proximal control (enzyme and substrate level effects) of $\mathrm{pH}$ on $\mathrm{N}_{2} \mathrm{O}$ reducing enzymes, which are more sensitive to low $\mathrm{pH}$ than the enzymes that reduce $\mathrm{NO}_{3}{ }^{-}$and $\mathrm{NO}_{2}{ }^{-}$; the former being more active at $\mathrm{pH}>7$ and the latter more active at $\mathrm{pH}<7$ (Richardson et al., 2009). Thus, $\mathrm{N}_{2} \mathrm{O}$ is produced at low $\mathrm{pH}$ but is not converted to $\mathrm{N}_{2}$ and tends to build up in the system because the activity of nitrous oxide reductase is inhibited. In most soils $\mathrm{N}_{2} \mathrm{O}$ emissions are smallest at neutral to basic pH (Liu et al., 2010), and our model predicts this; at a pH of 8 emissions were between $70 \%$ and $74 \%$ lower than at $\mathrm{pH} 6.5$, although total 
denitrification was greater (Figs. 2 and 3), and decreasing pH generally increased the $\mathrm{N}_{2} \mathrm{O}: \mathrm{N}_{2}$ ratio (Figs. 2 and 3 ). These results reflect the importance of $\mathrm{pH}$ not only as a dominant control on total denitrification, but also on the composition of the products; at pH values between 4 and 8 , the ratio $\mathrm{N}_{2} \mathrm{O}: \mathrm{N}_{2}$ increases as $\mathrm{pH}$ decreases, and below $\mathrm{pH} 4$ denitrification is largely inhibited due to negative impacts on denitrifying enzyme synthesis (Liu et al., 2010). Interestingly, at both sites the highest emissions $\mathrm{N}_{2} \mathrm{O}$ were predicted to occur at a pH of 5 (University Park, 58 gha $^{-1} \mathrm{~d}^{-1}$ and West Lafayette, 787 gha $^{-1} \mathrm{~d}^{-1}$ ) rather than at $\mathrm{pH} 4$ (University Park, 51 gha $^{-1} \mathrm{~d}^{-1}$ and West Lafayette, 630 gha $^{-1} \mathrm{~d}^{-1}$ ), as might be expected. This is because total denitrification $\left(\mathrm{N}_{2}+\mathrm{N}_{2} \mathrm{O}\right)$ was higher at $\mathrm{pH} 5$ than $\mathrm{pH}$, so despite the higher $\mathrm{N}_{2} \mathrm{O}: \mathrm{N}_{2}$ at pH 4, the quantity of $\mathrm{N}_{2} \mathrm{O}$ emitted at pH 4 was less than at pH 5 (Figs. 2 and 3). While total denitrification and $\mathrm{N}_{2} \mathrm{O}: \mathrm{N}_{2}$ were significantly higher at the West Lafayette site for the corn land use in the base model and all conditions tested in the SA compared to University Park, the effect of pH on denitrification gas flux is consistent between research sites and with the literature (e.g. Morkved et al., 2007; Liu et al., 2010; Richardson et al., 2009).

Soil C:N Ratio: Altering total soil C levels by $+/-10 \%, 20 \%$, and $50 \%$ had little impact on $\mathrm{N}_{2} \mathrm{O}$ emissions, which is somewhat surprising given that both systems were C-limited under all of the scenarios tested (e.g., initial C:N ratios 2.6:1 for PA and 1:0.8 for IN). Generally C:N ratios $<20: 1$ are considered C-limited (Richardson et al., 2009), so an increase in the C content would be expected to increase the denitrification rate. However, changing $\mathrm{C}$ levels resulted in very little change in emissions at either site ($5 \%$ to $3 \%$ in $\mathrm{PA}$, and $5 \%$ to $7 \%$ in $\mathrm{IN}$ ). With such low soil C:N ratios at the study sites, $\mathrm{N}_{2} \mathrm{O}$ emissions may have been overwhelmed by the effect of the relatively high $\mathrm{N}$ content of the soil; high $\mathrm{NO}_{3}{ }^{-}$ concentrations can inhibit $\mathrm{N}_{2} \mathrm{O}$ reduction as $\mathrm{NO}_{3}{ }^{-}$serves as an electron acceptor energetically preferable to $\mathrm{N}_{2} \mathrm{O}$. Indeed, emission were much more sensitive to the $\mathrm{N}$ application rate imparting a $-76 \%$ to $130 \%$ change on emissions at University Park and $-77 \%$ to $94 \%$ change at West Lafayette (Fig. 2). With respect to denitrification, the importance of the $\mathrm{N}$ application rate and by extension the soil $\mathrm{N}$ content is well established (Hai et al., 2009; Saggar et al., 2013) and the clear correlation between the $\mathrm{N}$ application rate and both total denitrification and $\mathrm{N}_{2} \mathrm{O}$ emissions was as expected under $\mathrm{C}$-limited conditions.

501 Temperature: Generally, increases in microbial activity are predicted as temperatures increase, but complex interactions among microbial processes that may be competing for soil nutrients make the net results difficult to predict. For example, some research has shown that increasing temperatures promote complete denitrification (reduction to $\mathrm{N}_{2}$ rather than halting at $\mathrm{N}_{2} \mathrm{O}$ ), which could reduce $\mathrm{N}_{2} \mathrm{O}$ emissions (Stres et al., 2008), but increasing temperatures also increase overall microbial activity, which 
could increase emissions of both products. Indeed, the results of our simulations with respect to increased temperature (Fig. 2) suggest complex interactions, where moderate increases in temperature (+10\% and $20 \%)$ at University Park slightly increased emissions (1-6\%) but the $30 \%$ temperature increase actually decreased emissions $1 \%$. At West Lafayette increases in temperatures decreased emissions (1518\%). Decreases in temperature at both sites increased $\mathrm{N}_{2} \mathrm{O}$ emissions $3-28 \%$ (Fig. 2). $\mathrm{N}_{2}$ and total denitrification (Fig. 2) are similarly affected, the highest total denitrification and $\mathrm{N}_{2}$ emissions occur at a differences in the soil types (sandy clay loam at University Park and loam at West Lafayette) and soil moisture status (precipitation quantity and timing differing between the sites) that affect how changes in air temperature translate to changes in the soil temperature (e.g., there is a dampened lag).

Soil Moisture, $\theta$ : Changes in $\theta$ do not produce a linear nor directionally consistent response in $\mathrm{N}_{2} \mathrm{O}$ emissions. Changes in $\theta$ can cause rapid shifts between nitrification and denitrification (Bergsma et al., 2002; Webster et al., 1996). As $\theta$ decreases pore space oxygen concentrations increase, most denitrification to ceases, and nitrification rapidly becomes the dominant $\mathrm{N}$ transformation process. Return to anaerobic conditions causes a similar reversal to denitrification. These periods of transition often coincide with peak periods of $\mathrm{N}_{2} \mathrm{O}$ flux, especially in agricultural soils (Butterbach-Bahl et al., 2011). Indeed, the effect of soil moisture on $\mathrm{N}_{2} \mathrm{O}$ emissions in Fig. 2 could be partially explained by the temporal dynamics of soil wetting/drying. However, while more frequent wetting and drying at University Park (data not shown) might lead us to expect higher $\mathrm{N}_{2} \mathrm{O}$ emissions, the $\mathrm{N}_{2} \mathrm{O}: \mathrm{N}_{2}$ ratio is higher at West Lafayette, presumably due to the greater soil $\mathrm{N}$ levels at West Lafayette $(1800 \mathrm{~kg} / \mathrm{ha}$ compared to $650 \mathrm{hg} / \mathrm{ha}$ at University Park), the higher levels of total denitrification, about ten times greater than University Park, are expected.

All of these factors interact in complex ways, which limits the value of conclusions drawn from assessing their individual impact. For instance, temperature affects $\mathrm{C}: \mathrm{N}$ ratio by changing the rate of $\mathrm{C}$ decomposition and $\mathrm{N}$ cycling. Temperature also alters $\theta$ by changing evapotranspiration and plant moisture uptake. Increasing total soil $\mathrm{C}$ can also increase the water holding capacity of the soil and in turn increase $\theta$ as well. An integrated model capable of capturing these complex interactions is one of the only ways to assess how $\mathrm{N}_{2} \mathrm{O}$ emissions change under altered environmental conditions. SWAT-GHG was able to reliably predict how these factors affect $\mathrm{N}_{2} \mathrm{O}$ emission and is thus useful for assessing the impact of targeted landscape management on $\mathrm{N}_{2} \mathrm{O}$ emissions. 
Implications for Modeling: Accurate prediction of the spatial and temporal extent of GHG emissions is critical for managing agricultural nutrients. Despite some discrepancies in the timing or magnitude of peak $\mathrm{N}_{2} \mathrm{O}$ emissions (e.g., Figs. 4 and 6), SWAT-GHG simulated $\mathrm{N}_{2} \mathrm{O}$ emissions well at both sites. The reason for discrepancies might be due to the several factors; 1 ) the dynamic nature of $\mathrm{N}_{2} \mathrm{O}$ emissions that can vary dramatically over the course of a day [e.g., the model integrates over a $24 \mathrm{hr}$ period, while the measurements integrate over a $1 \mathrm{hr}$ period (Parkin and Venterea, 2010)]; 2) the uncertainty in the input data (e.g., amount and time of application of fertilizer, soil pH, missed precipitation event); or 3) process conceptualization in the model itself. However, compared to other denitrification $/ \mathrm{N}_{2} \mathrm{O}$ models SWAT-GHG simulated the spatial and temporal $\mathrm{N}_{2} \mathrm{O}$ emissions from agroecosystems as well or better than most other models in the literature. For instance, Parton et al. (2001) who developed DAYCENT were able to simulate annual and monthly $\mathrm{N}_{2} \mathrm{O}$ emissions well but daily emissions were poorly predicted; the authors speculate that this is due to the effect of topography redistributing soil moisture, which DAYCENT was not developed to capture. Morse et al. (2012) suggest that finer temporal (and spatial) scale models that can capture the variability of $\mathrm{N}_{2} \mathrm{O}$ emission are critical to better managing landscape scale GHG emissions. SWAT-GHG provides these enhanced simulation capabilities for agroecosystems by linking the effect of topography (SWAT-GHG is based on the SWAT-VSA model which incorporates the impact of topography) and the processes controlling GHG emissions. Indeed, the incorporation of more mechanistic soil moisture predictions represents an improvement on previous modeling efforts. Although the model generally simulates $\mathrm{N}_{2} \mathrm{O}$ emissions well, there are some areas where the model could be improved, such as including dynamic soil pH calculation (e.g. currently pH in is a user defined, static input). Addition of dynamic $\mathrm{pH}$ would allow the quantification of the impact of management practices, such as liming and/or use of acidifying fertilizers, on $\mathrm{N}_{2} \mathrm{O}$ emissions over time.

SWAT-GHG can be used and applied to agroecosystems at a range of scales, crop types and management regimes and used to test scenarios related to crop production, agricultural best management practices and climate change. This would allow managers to identify areas of the landscape that have a high emissions and a high potential for management practices to reduce emissions. For instance, the model can be used to assess the impacts of management practices such as tillage, drainage water management, nutrient management, and soil amendments on GHG emissions or for assessing the impact of climate change on $\mathrm{N}_{2} \mathrm{O}$ emissions. 


\section{Conclusions}

This paper describes SWAT-GHG, a new routine for the SWAT model to predict $\mathrm{N}_{2} \mathrm{O}$ emissions in agroecosystems using soil and environmental factors such as soil $\mathrm{N}$ and $\mathrm{C}$ content, soil temperature, soil $\mathrm{pH}$, and soil $\theta$ as the controlling factors. The base model upon which SWAT-GHG was developed incorporates the impact of topography on the redistribution on soil water. The model was tested for different crop types and compared with measured $\mathrm{N}_{2} \mathrm{O}$ values at two test sites: University Park, PA and West Lafayette, IN. The model simulated $\mathrm{N}_{2} \mathrm{O}$ well in both time and space as verified by comparison to measured $\mathrm{N}_{2} \mathrm{O}$ flux from different crop types. Perhaps more importantly, the model was sensitive to changes in soil and environmental factors such as soil pH, soil nutrient content and precipitation. This new model represents an advance over many existing GHG emission models in several respects; 1 ) it incorporates the physical processes controlling $\mathrm{N}_{2} \mathrm{O}$ emissions; 2) it uses easily available input parameters to initialize; 3) it provides predictions at the subfield scale; and 4) it is able to capture emission at a high temporal frequency.

\section{Acknowledgements}

This research is based on work supported by the National Science Foundation (NSF) under Grant No. CBET-1360280.

\section{References}

Arah, J. R. M., \& Smith, K. A. (1989). Steady state denitrification in aggregated soilsAmathematical model. Journal of Soil Science, 40(1), 139-149.

Arnold, J. G., Srinivasan, R., Muttiah, R. S., \& Williams, J. R. (1998). Large Area Hydrologic Modeling and Assessment Part I: Model Development. Journal of American Water Resources Association, 34(1), 73-89. doi:10.1111/j.1752-1688.1998.tb05961.x

Beheydt, D. ,Boeckx, P., Ahmed, H. P., \& Van Cleemput, O. (2008). N2O emission from conventional and minimum-tilled soils. Biology and Fertility of Soils, 44(6), 863-873. doi:10.1007/s00374-008-0271-9

Bennett, N. D., Croke, B. F. W., Guariso, G., Guillaume, J. H. A. ,Hamilton, S. H., Jakeman, A. J., Marsili-Libelli, S., Newham, L. T. H., Norton, J. P., Perrin, C., Pierce, S.A., Robson, B., Seppelt, R., Voinov, A. A., Fath, B. D. , \& Andreassian, V. (2013). Characterising performance of environmental models. Environmental Modelling \& Software, 40, 1-20. doi:http://dx.doi.org/10.1016/i.envsoft.2012.09.011

Bergsma, T. T., Robertson, G. P. , \& Ostrom, N. E. (2002). Influence of soil moisture and land use history on denitrification end-products. Journal of Environmental Quality, 31(3), 711-717. 
Bruland, G. L., Richardson, C. J. , \& Whalen, S. C. (2006). Spatial variability of denitrification potential and related soil properties in created, restored, and paired natural wetlands. Wetlands, 26(4), 1042-1056. doi:10.1672/0277-5212(2006)26[1042:svodpa]2.0.co;2

Butterbach-Bahl, K., \& Dannenmann, M. (2011). Denitrification and associated soil N2O emissions due to agricultural activities in a changing climate. Current Opinion in Environmental Sustainability, 3(5), 389-395. doi:DOI 10.1016/j.cosust.2011.08.004

Clement, J. C., Pinay, G., \& Marmonier, P. (2002). Seasonal dynamics of denitrification along topohydrosequences in three different riparian wetlands. Journal of Environmental Quality, 31(3), 1025-1037. doi:10.2134/jeq2002.1025

Dannenmann, M., Butterbach-Bahl, K., Gasche, R., Willibald, G. , \& Papen, H. (2008). Dinitrogen emissions and the N2:N2O emission ratio of a Rendzic Leptosol as influenced by $\mathrm{pH}$ and forest thinning. Soil Biology and Biochemistry, 40(9), 2317-2323. doi:10.1016/j.soilbio.2008.05.009

Del Grosso, S., Ojima, D., Parton, W., Mosier, A., Peterson, G. , \& Schimel, D. (2002). Simulated effects of dryland cropping intensification on soil organic matter and greenhouse gas exchanges using the DAYCENT ecosystem model. Environmental Pollution, 116, S75-S83. doi:10.1016/s0269-7491(01)00260-3

Del Grosso, S., White, J., Wilson, G., Vandenberg, B., Karlen, D., Follett, R., Johnson, J., Franzluebbers, A., Archer, D. , \& Gollany, H. (2013). Introducing the GRACEnet/REAP data contribution, discovery, and retrieval system. Journal of Environmental Quality, 42(4), 1274-1280.

Easton, Z. M., Fuka, D. R., Walter, M. T., Cowan, D. M., Schneiderman, E. M. , \& Steenhuis, T. S. (2008). Re-conceptualizing the soil and water assessment tool (SWAT) model to predict runoff from variable source areas. Journal of Hydrology, 348(3), 279-291. doi:10.1016/j.jhydrol.2007.10.008

Frolking, T. A., Changsheng, L. I. , \& Frolking, S. (1992). A model of nitrous oxide evolution from soil driven by rainfall events. I - Model structure and sensitivity. II - Model applications. Journal of Geophysical Research, 97(D9).

Grant, R. F. (1991). A Technique for Estimating Denitrification Rates at Different Soil Temperatures, Water Contents, and Nitrate Concentrations. Soil Science, 152(1), 41-52. doi:10.1097/00010694-199107000-00007

Groffman, P. M., Butterbach-Bahl, K., Fulweiler, R. W., Gold, A. J., Morse, J. L., Stander, E. K., Tague, C., Tonitto, C. , \& Vidon, P. (2009). Challenges to incorporating spatially and temporally explicit phenomena (hotspots and hot moments) in denitrification models. Biogeochemistry, 93(1/2), 49-77. doi:10.1007/s10533-008-9277-5

Guenther, G. , \& Maune, D. (2007). Digital elevation model technologies and applications: the DEM users manual. Airborne LiDAR bathymetry, 2nd edn. American Society for Photogrammetry and Remote Sensing, USA, 253-320.

Hai, B., Diallo, N. H., Sall, S., Haesler, F., Schauss, K., Bonzi, M., Assigbetse, K., Chotte, J.-L., Munch, J. C. , \& Schloter, M. (2009). Quantification of key genes steering the microbial nitrogen cycle in the rhizosphere of sorghum cultivars in tropical agroecosystems. Applied and Environmental Microbiology, 75(15), 4993-5000.

Hansen, S., Jensen, H. E., Nielsen, N. E. , \& Svendsen, H. (1991). Simulation of nitrogen dynamics and biomass production in winter-wheat using the Danish simulation model DAISY. Fertilizer Research, 27(2-3), 245-259. doi:10.1007/BF01051131 
Heinen, M. (2006). Simplified denitrification models: Overview and properties. Geoderma, 133(3), 444-463. doi:10.1016/j.geoderma.2005.06.010

Henault, C. , \& Germon, J. C. (2000). NEMIS, a predictive model of denitrification on the field scale. European Journal of Soil Science, 51(2), 257-270. doi:DOI 10.1046/j.13652389.2000.00314.x

Jahangir, M. M. R., Johnston, P., Addy, K., Khalil, M. I., Groffman, P. M. , \& Richards, K. G. (2013). Quantification of In Situ Denitrification Rates in Groundwater Below an Arable and a Grassland System. Water, Air, \& Soil Pollution, 224(9), 1-14. doi:10.1007/s11270013-1693-z

Kelly, R. A., Jakeman, A. J., Barreteau, O., Borsuk, M. E., ElSawah, S., Hamilton, S. H., Henriksen, H. J., Kuikka, S., Maier, H. R., Rizzoli, A. E., van Delden, H. , \& Voinov, A. A. (2013). Selecting among five common modelling approaches for integrated environmental assessment and management. Environmental Modelling \& Software, 47, 159-181. doi:http://dx.doi.org/10.1016/j.envsoft.2013.05.005

Kemanian, A. R. , \& Stöckle, C. O. (2010). C-Farm: A simple model to evaluate the carbon balance of soil profiles. European Journal of Agronomy, 32(1), 22-29. doi:10.1016/j.eja.2009.08.003

Knowles, R. (1982). Denitrification. Microbiological reviews, 46(1), 43-70.

Kragt, M. E., Newham, L. T. H., Bennett, J. , \& Jakeman, A. J. (2011). An integrated approach to linking economic valuation and catchment modelling. Environmental Modelling \& Software, 26(1), 92-102. doi:http://dx.doi.org/10.1016/j.envsoft.2010.04.002

Leffelaar, P. A. (1988). Dynamics of Partial Anaerobiosis, Denitrification, and Water in a Soil Aggregate. Soil Science, 146(6), 427-444. doi:10.1097/00010694-198812000-00004

Leffelaar, P. A. , \& Wessel, W. W. (1988). Denitrification in a Homogeneous, Closed System. Soil Science, 146(5), 335-349. doi:10.1097/00010694-198811000-00006

Li, C., Frolking, S., Crocker, G. J., Grace, P. R., Klír, J., Körchens, M. , \& Poulton, P. R. (1997). Simulating trends in soil organic carbon in long-term experiments using the DNDC model. Geoderma, 81(1), 45-60. doi:10.1016/S0016-7061(97)00080-3

Li, Y., White, R., Chen, D., Zhang, J., Li, B., Zhang, Y., Huang, Y. , \& Edis, R. (2007). A spatially referenced water and nitrogen management model (WNMM) for (irrigated) intensive cropping systems in the North China Plain. Ecological Modelling, 203(3), 395423. doi:10.1016/j.ecolmodel.2006.12.011

Metivier, K. A., Pattey, E. , \& Grant, R. F. (2009). Using the ecosys mathematical model to simulate temporal variability of nitrous oxide emissions from a fertilized agricultural soil. Soil Biology and Biochemistry, 41(12), 2370-2386. doi:10.1016/j.soilbio.2009.03.007

Moriasi, D. N., Gitau, M. W., Pai, N. , \& Daggupati, P. (2015). Hydrologic and water quality models: Performance measures and evaluation criteria. Transactions of the ASABE, 58(6), 1763-1785.

Mørkved, P. T., Dörsch, P. , \& Bakken, L. R. (2007). The N 2 O product ratio of nitrification and its dependence on long-term changes in soil pH. Soil Biology and Biochemistry, 39(8), 2048-2057.

Morse, J. L., Ardón, M. , \& Bernhardt, E. S. (2012). Using environmental variables and soil processes to forecast denitrification potential and nitrous oxide fluxes in coastal plain wetlands across different land uses. Journal of Geophysical Research: Biogeosciences, 117(G2), n/a-n/a. doi:10.1029/2011JG001923 
Mosier, A. R., Doran, J. W. , \& Freney, J. R. (2002). Managing soil denitrification. Journal of Soil and Water Conservation, 57(6), 505-513.

Norton, J. (2015). An introduction to sensitivity assessment of simulation models. Environmental Modelling \& Software, 69, 166-174. doi:http://dx.doi.org/10.1016/j.envsoft.2015.03.020

Parkin, T.B. and Venterea, R.T. 2010. Sampling Protocols. Chapter 3. Chamber-Based Trace Gas Flux Measurements. In Sampling Protocols. R.F. Follett, editor. p. 3-1 to 3-39. Available at: www.ars.usda.gov/research/GRACEnet

Parton, W. J., Hartman, M., Ojima, D. , \& Schimel, D. (1998). DAYCENT and its land surface submodel: description and testing. Global and Planetary Change, 19(1), 35-48. doi:10.1016/S0921-8181(98)00040-X

Parton, W. J., Holland, E. A., Del Grosso, S. J., Hartman, M. D., Martin, R. E., Mosier, A. R., Ojima, D. S. , \& Schimel, D. S. (2001). Generalized model for NOxand N2O emissions from soils. Journal of Geophysical Research: Atmospheres, 106(D15), 17403-17419. doi:10.1029/2001jd900101

Parton, W. J., Mosier, A. R., Ojima, D. S., Valentine, D. W., Schimel, D. S., Weier, K. , \& Kulmala, A. E. (1996). Generalized model for N2and N2O production from nitrification and denitrification. Global Biogeochemical Cycles, 10(3), 401-412. doi: $10.1029 / 96 \mathrm{gb} 01455$

Pianosi, F., Beven, K., Freer, J., Hall, J. W., Rougier, J., Stephenson, D. B. , \& Wagener, T. (2016). Sensitivity analysis of environmental models: A systematic review with practical workflow. Environmental Modelling \& Software, 79, 214-232. doi:http://dx.doi.org/10.1016/j.envsoft.2016.02.008

Priesack, E., Achatz, S. , \& Stenger, R. (2001). Parameterization of soil nitrogen transport models by use of laboratory and field data. Modeling Carbon and Nitrogen Dynamics for Soil Management. CRC Press Inc., Boca Raton, Florida, 461-484.

Richardson, D., Felgate, H., Watmough, N., Thomson, A. , \& Baggs, E. (2009). Mitigating release of the potent greenhouse gas $\mathrm{N} 2 \mathrm{O}$ from the nitrogen cycle-could enzymic regulation hold the key? Trends in Biotechnology, 27(7), 388-397.

Riley, W. , \& Matson, P. (2000). NLOSS: A mechanistic model of denitrified N2O and N2 evolution from soil. Soil Science, 165(3), 237-249.

Rochester, I. J. (2003). Estimating nitrous oxide emissions from flood-irrigated alkaline grey clays. Australian Journal of Soil Research, 41(2), 197-206. doi:10.1071/SR02068

Saggar, S., Jha, N., Deslippe, J., Bolan, N. S., Luo, J., Giltrap, D. L., Kim, D. G., Zaman, M. , \& Tillman, R. W. (2013). Denitrification and N2O:N2 production in temperate grasslands: Processes, measurements, modelling and mitigating negative impacts. Science of the Total Environment, 465, 173-195. doi:http://dx.doi.org/10.1016/j.scitotenv.2012.11.050

Saltelli, A. , \& Annoni, P. (2010). How to avoid a perfunctory sensitivity analysis. Environmental Modelling \& Software, 25(12), 1508-1517. doi:http://dx.doi.org/10.1016/j.envsoft.2010.04.012

Seligman, N. G. , \& Keulen, H. v. (1981). PAPRAN: a simulation model of annual pasture production limited by rainfall and nitrogen Conference, p.192-221.

Shaffer, M. J. (2002). Nitrogen modeling for soil management. Journal of Soil and Water Conservation, 57(6), 417-425.

Shaffer, M. J., Halvorson, A. D. , \& Pierce, F. J. (1991). Nitrate leaching and economic analysis package (NLEAP): model description and application. Managing Nitrogen for Groundwater Quality and Farm Profitability, 285-322. 
Shaffer, M. J., Ma, L. , \& Hansen, S. (2001). Modeling Carbon and Nitrogen Dynamics for Soil Management: CRC Press.

Simek, M. , \& Cooper, J. E. (2002). The influence of soil pH on denitrification: progress towards the understanding of this interaction over the last 50 years. European Journal of Soil Science, 53(3), 345-354. doi:10.1046/j.1365-2389.2002.00461.x

Stres, B., Danevčič, T., Pal, L., Fuka, M. M., Resman, L., Leskovec, S., Hacin, J., Stopar, D., Mahne, I. , \& Mandic-Mulec, I. (2008). Influence of temperature and soil water content on bacterial, archaeal and denitrifying microbial communities in drained fen grassland soil microcosms. FEMS Microbiology Ecology, 66(1), 110-122.

Tian, H., Chen, G., Lu, C., Xu, X., Ren, W., Zhang, B., Banger, K., Tao, B., Pan, S., Liu, M., Zhang, C., Bruhwiler, L. , \& Wofsy, S. (2015). Global methane and nitrous oxide emissions from terrestrial ecosystems due to multiple environmental changes. Ecosystem Health and Sustainability, 1(1), 1-20. doi:10.1890/EHS14-0015.1

Vinten, A. J. A., Castle, K. , \& Arah, J. R. M. (1996). Field evaluation of models of denitrification linked to nitrate leaching for aggregated soil. European Journal of Soil Science, 47(3), 305-317. doi:10.1111/j.1365-2389.1996.tb01404.x

Webster, E. A. , \& Hopkins, D. W. (1996). Contributions from different microbial processes to $\mathrm{N} 2 \mathrm{O}$ emission from soil under different moisture regimes. Biology and Fertility of Soils, 22(4), 331-335. doi:10.1007/BF00334578

Weier, K. L., Doran, J. W., Power, J. F. , \& Walters, D. T. (1993). Denitrification and the dinitrogen nitrous-oxide ratio as affected by soil-water, available carbon, and nitrate. Soil Science Society of America Journal, 57(1), 66-72. doi:10.2136/sssaj1993.03615995005700010013x

Williams, J. (1990). Sharply A N. EPIC-Erosion Productivity Impact Calculator I. Model Documentation, 1768.

Wu, Y., Liu, S., Qiu, L. , \& Sun, Y. (2016). SWAT-DayCent coupler: An integration tool for simultaneous hydro-biogeochemical modeling using SWAT and DayCent. Environmental Modelling \& Software, 86, 81-90. doi:http://dx.doi.org/10.1016/j.envsoft.2016.09.015

Zhang, D., Chen, X., Yao, H. , \& James, A. (2016). Moving SWAT model calibration and uncertainty analysis to an enterprise Hadoop-based cloud. Environmental Modelling \& Software, 84, 140-148. doi:http://dx.doi.org/10.1016/j.envsoft.2016.06.024 